\title{
GLOBAL COMMODITY CHAINS AND THE SPATIAL-TEMPORAL DIMENSIONS OF LABOR CONTROL: LESSONS FROM COLOMBIA'S COFFEE AND BANANA INDUSTRIES
}

\author{
Phillip Hough \\ Department of Sociology \\ Florida Atlantic University \\ Phough2@fau.edu
}

\begin{abstract}
In this paper, the author seeks to explain the trajectories of local labor regime dynamics in Colombia's coffee and banana industries from the post war developmental decades until the present. In order to explain these dynamics, the author first develops a neo-Gramscian ideal-typical schema to highlight the full range of labor regime dynamics emergent in Colombia, including "hegemonic," "despotic," and "crisis" regimes. The author then develops a theory of local labor regime types that draws from Giovanni Arrighi's work on commodity chains. Finally, using comparative and world-historical methods, the author finds that the shifting trajectories of labor regimes in Colombia are affected by the nodal location of these regimes within their respective commodity chains
\end{abstract}

For those of us who pay attention to the state of labor relations in the current era, to overhear someone mention the word "labor" in the same sentence as "Colombia" is enough to make your head turn expecting to hear yet another dismal story about a labor activist falling victim to military or paramilitary violence. In fact, a 2002 International Confederation of Trade Unions report noted that since the 1980s over 3,800 unionists and labor activists have been assassinated (ICFTU 2002). And while the number of trade unionists murdered declined between 2003 and 2007, these killings and the miserably high levels of impunity associated with them, have actually escalated over the past few years. Indeed, a recent 2008 International Trade Union Confederation report found that more trade unionists have been murdered in Colombia since president Álvaro Uribe Vélez took office in 2002 than in the rest of the world combined, making Colombia the "the most dangerous place in the world to be a trade unionist" (USLEAP 2008).

Interestingly, labor relations in Colombia were not always, or predominantly, characterized by this repressive form of labor control. In his seminal work, Labor in Latin America (1986), labor historian Charles Bergquist compared the divergent political-economic trajectories of Argentina, Chile, Venezuela and Colombia as each post-colonial society transformed itself into developmental capitalist nation-states by the decades immediately following the Second World War. In contrast to the "socialist" trajectory of Chile, the "right-wing popular nationalist" trajectory of Argentina, and the "liberal-nationalist" trajectory of Venezuela, Bergquist found that postwar Colombia was characterized by the perpetuation of an "archaic" and "particularly exploitative" political-economic system dominated by elites of the same Liberal and

Copyright @2010, American Sociological Association, Volume XVI, Number 2, Pages 123-161 ISSN 1076-156X 


\section{LESSONS FROM COLOMBIA 124}

Conservative traditional parties who ruled throughout the $19^{\text {th }}$ century. Most striking about the Colombian case to Bergquist was the active participation of Colombia's working class and subaltern groups in their own subordination to liberal capitalist development. Rather than attribute this form of working class complacency to the repressiveness of the country's elites, Bergquist argues that this resulted from the "lived experiences" of the coffee-producing peasantry themselves, the heart of the nation's export sector and the largest laboring population, who consolidated a form of "working-class cultural values that continue to guarantee the ideological domination of the liberal ruling class, the ongoing political hegemony of the traditional parties, and the enduring obstacles to combative collective organization of the working class" (Bergquist 1986: 375).

Bergquist is correct to point out that Colombia's conservative albeit "hegemonic" developmental model differed from the general trajectories of other Latin American nations, where working class militancy was either forcibly repressed by authoritarian rulers or had given way to socialist experiments during the postwar decades. Yet, if one were to look at forms of labor control from a sub-national, micro-regional perspective within Colombia rather than a comparative-national perspective, one would see a highly uneven distribution of coercion and consent. In fact, at the time that the small-holding coffee producing farmers of Colombia's central "coffee axis" region of Viejo Caldas were incorporated as willing "junior partners" into a hegemonic project led by the sector's mercantile coffee elite, the country's key "banana-axis" region of Urabá was becoming consolidated through a coercive form of labor control with severe (and generally effective) repression of banana workers both on the plantations and in the political arena. The existence of this "coercive side" of Colombian class relations characterizing the banana export sector flies in the face of scholars, Bergquist included, who commonly emphasize Colombia's adherence to regular elections, civilian forms of rule, and liberal-democratic principles during the postwar decades (Martz 1997).

Ironically, around the time of Bergquist's writing of Labor and Latin America, the conditions that stabilized both the active consent of the coffee producing peasantry of Viejo Caldas and the repression of the banana workers of Urabá during the postwar decades were rapidly unraveling. By the middle of the 1980s, working class militancy coupled with leftist guerrilla insurgency in the banana region of Urabá had grown to threaten the class position of local political and economic elites; and these elites in turn responded with a wave of brutal state and paramilitary violence in order to regain control of the region. The coffee sector, which had remained impervious to the types of leftist insurgency and working class militancy characterizing other regions in the postwar decades, suddenly succumbed to its own wave of social mobilization, guerrilla warfare, and state and paramilitary violence. In fact, by the middle years of the 1990s, when most Latin American societies were witnessing the disarmament of guerrilla insurgency groups and a renewed emphasis on pacific forms of political participation (O'Donnell et al. 1993; Diamond et al. 1999; Foran et al. 2003), levels of political violence in Colombia escalated to unprecedented heights (as evidenced by Figure 1 below). By the turn of the century, scholars no longer described Colombia as characterized by either consensual or coercive forms of class rule, but instead spoke of "ongoing crisis" and the real possibility of state breakdown. Colombia's reputation had become synonymous with political violence and illegal economic activity, including cocaine exports, kidnapping, and mass killings (Livingstone 2004; Rojas and Meltzer 2005). This escalation in political violence and endemic crisis at the turn of the century has been a key reason for the election (and re-election) of President Uribe, whose "democratic security" 
policies have attempted to squash leftist opposition, including labor militancy, through increased military spending while consistently downplaying the military's relations with violent paramilitary groups.

Figure 1. Rates (0-90) and Incidents (0-300,000) of Violence in Colombia, 1959-1997

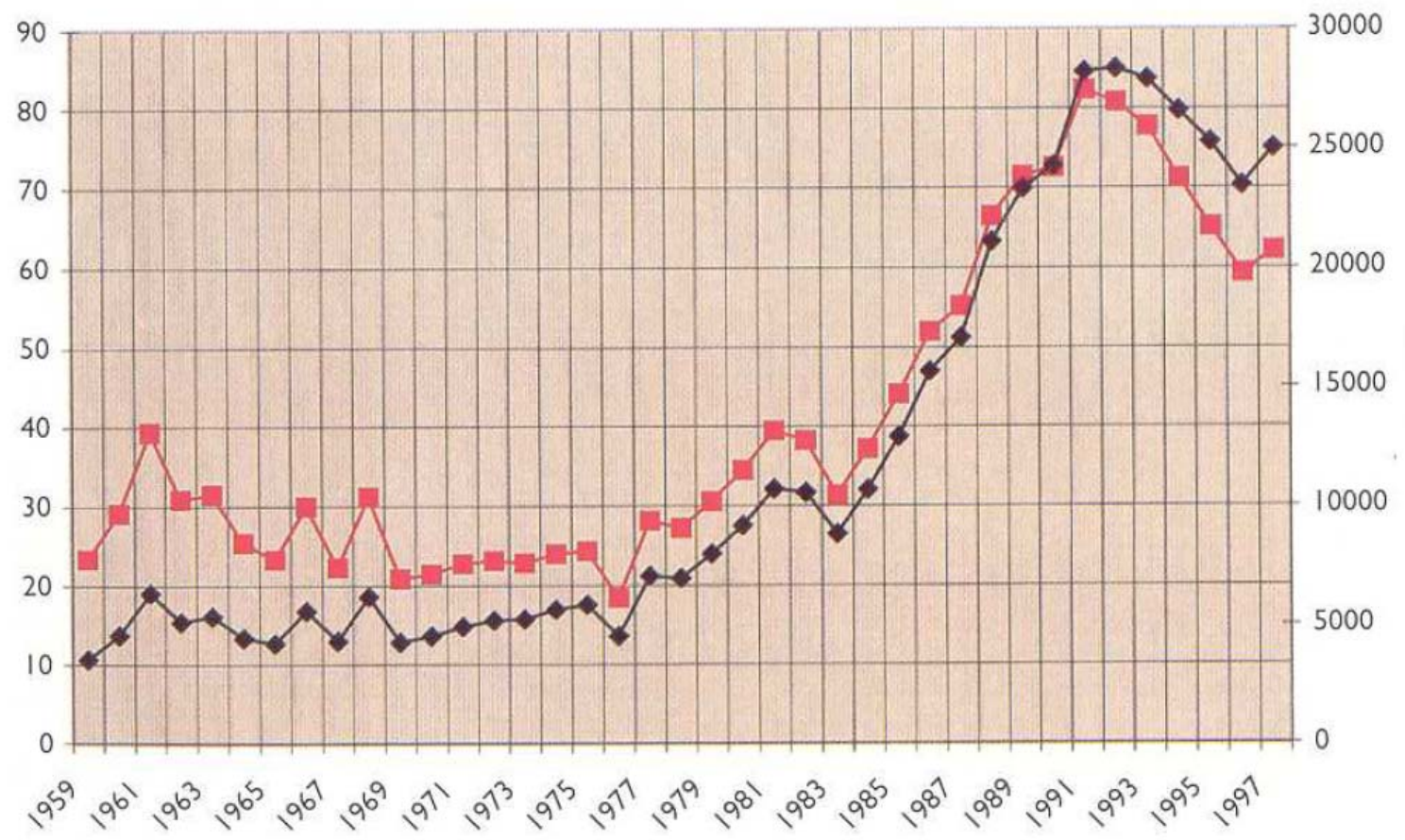

Source: Published in Cubides et al. 1990.

If the first puzzle driving this essay entails a specific spatial question: why such starkly different labor regime types existed within Colombia during the postwar developmental decades, then the second puzzle entails a temporal question: why these relatively stable (albeit contrasting) forms of labor regimes in the coffee and banana regions collapsed suddenly in the 1980s and 1990s, leading to a period of worker militancy and elite repression - a crisis of elite control in which neither hegemony nor effective repression prevailed.

In order to solve these puzzles, I draw from an eclectic theoretical toolkit that includes concepts derived from the literatures on global commodity chains, neo-Gramscian theories of labor regimes, and world historical sociology. The paper proceeds in three sections. I begin the first section with a critique of the existing sociological literature on labor regimes for its tendency to generalize from the experiences of contemporary workers in the global north. In doing so, the literature tends to over-emphasize "indirect" market-based mechanism of instilling labor control and de-emphasize "direct" forms of state and para-state repression of worker militancy. Likewise, the literature tends to over-emphasize the stability of capitalist labor regimes and de-emphasize the capacity of workers to subvert capitalist production and propel capital accumulation processes into periods of crisis. In order to rectify these limitations, I develop a neo-Gramscian ideal-typical schema that distinguishes regimes characterized by the effective domination of workers - ranging 


\section{LESSONS FROM COLOMBIA 126}

from consensual domination ("hegemony”) to coercive domination (“despotism”) - from regimes in which capitalist elites no longer control the laboring population in the region ("crises of control"). These ideal-types allow us to see that the trajectory of the coffee region is best characterized as a shift from a hegemonic labor control regime in the postwar decades to a crisis of control by the 1990s. Likewise, labor regime dynamics in the banana region shifted from despotism in the postwar decades to a crisis of control in the 1980s, only to return to a despotic regime by the 1990s.

I argue that theoretical concepts developed in the literature on commodity chains, especially Arrighi and his collaborators' work relating core-periphery location to the uneven geography of wealth under historical capitalism, are particularly well suited to help us explain the divergent labor regime dynamics in Colombia. Arrighi argues that core-periphery nodal locations along any given chain are best characterized by the capacity of their firms to externalize market competition onto other chain actors and therefore accumulate monopoly profits. I hypothesize that this core-periphery dynamic will have a determining impact on the labor regimes constituting that nodal location due to the capacity of local elites to use the wealth they capture along the chain to reinvest in both profitability concerns (further capital accumulation) and legitimacy concerns (redistributionary measures that bolster their legitimacy vis-à-vis the local working class). In this sense, elites in core locations may utilize their profits to establish a hegemonic regime that incorporates local workers as "junior partners" without threatening their profitability. In contrast, peripheral elites are squeezed tightly between profitability and legitimacy concerns, forcing them to externalize the costs of market competition onto their respective workers by cutting redistributionary efforts. This "peripheral squeeze" explains the structural context in which state and/or private forms of elite violence becomes more likely.

In the second section of the paper, I use this Arrighian commodity chains framework to explain the existence of stable, albeit contrasting, labor regimes constituting Colombia's coffee and banana industries in the postwar decades (the spatial puzzle). I find that these regimes were indeed affected by their nodal location along each respective commodity chain. Hegemony in the coffee region was premised upon the capacity of the region's mercantile elites to capture core-like profits that were reinvested in the well-being of the smallholding coffee farmer population through various redistributionary measures. In contrast, the despotic labor regime characterizing Colombia's banana region resulted from an inability and/or unwillingness of the local planter elite to reinvest in similar redistributionary measures. As a result, Urabá's elites came to rely upon repressive measures of the state to curtail worker militancy. Moreover, I found that these core-periphery locations along each commodity chain were not over-determined or fixed over time. Rather, these positions (and the implications they have on local labor regime types) depended in important ways on the agency of Colombia's coffee and banana elites, who engaged in collective action strategies in an effort to "upgrade" from peripheral to core locations and therefore increase the levels of wealth captured. The hegemonic regime characterizing the coffee region resulted from successful restructuring of the global coffee market (via the International Coffee Agreement, 1961-1989), which shifted the position of Colombia's coffee sector from a peripheral to a core-like location along the chain. That is, the collective action efforts of Colombia's coffee capitalists were successful in taking advantage of the world historical opportunities to "move up" the coffee chain to accrue core-like profits that were reinvested in a local hegemonic labor regime. Colombia's banana capitalists also attempted to restructure the world banana market during the postwar decades during the same world historical period. Yet, 
rather than move up the banana chain or fundamentally restructure profits along the chain as had occurred in the world coffee market, Colombia's banana capitalists were only able to "move into" a peripheral location along the global banana chain. Facing a competitive world market, Colombia's banana capitalists came to rely heavily upon state coercion to repress banana worker demands for a local redistribution of the wealth accumulated.

I address the temporal puzzle in the third part of this paper. Here I show that that shift from consent to crisis in the coffee industry was caused by the "downgrading" of Colombia's capitalists to a peripheral node (following the abrogation of the International Coffee Agreement) that created a crisis of control for local elites. In contrast, the shift to a crisis of control scenario in the banana region in the 1980s was not due to a shift in the location of the node along the chain, which remained peripheral. Rather, it arose following a democratization of the national political regime, which forced the region's elites to redistribute profits to workers and opened up spaces for greater worker control over the region's political economy. Threatened by greater work control and unable to ameliorate the situation through redistributionary efforts, the region's elites responded with a wave of paramilitarism that effectively repressed worker militancy and restored profitability to the sector.

\section{RETHINKING LABOR REGIMES AND COMMODITY CHAINS}

\section{Distinguishing Labor Regime Types: Consent, Coercion and Crisis}

It is widely understood by labor scholars that the nature of production under historical capitalism creates a contradictory structural relationship between working classes whose labor power is used to reproduce their subsistence as well as to produce surplus value in the form of capitalist profits and capitalists whose livelihood is premised upon the capacity to extract surplus labor power from workers. This system of production rests upon the existence of a "free labor market," wherein capitalists own the means of production but do not "own" the workers themselves, who sell their labor power to capitalists for a wage. To the degree to which workers can make a livelihood elsewhere, capitalists must finds means to assure worker participation in the labor process. Labor control, or the need for capital to oversee and direct the conditions under which labor power is reproduced and integrated into the labor process, is therefore a fundamental tension characterizing capitalist relations of production (Marx 1976 [1867]; Burawoy 1983 and 1985; Jonas 1995: 325).

In his analysis of the rise of the British working class, Karl Marx himself found that labor control emerged through the dispossession of the rural peasantry from the land (the so-called "original" or "primitive accumulation" process), which forced workers to seek a livelihood in a free labor market as wage workers. Later scholars, however, have pointed out that this mode of labor control via the creation of a labor market and the dispossession of the rural population is not the only or even the most common form of labor control to emerge under historical capitalism. One of the earliest theorists of labor regime variants was Antonio Gramsci (1971 [1926]), who argued that the working classes of the "economically advanced" states of Western Europe and the United States spontaneously and actively participated in capitalist forms of production ("hegemony") while those in the "economically backwards" states of Eastern Europe and Russia only submitted to capitalist forms of production through the use of direct state coercion. To be 


\section{LESSONS FROM COLOMBIA 128}

sure, Gramsci believed that capitalism as a social system is ultimately premised upon the capacity to use direct forms of coercion to propel workers into the capitalist labor process, and that both consent and elite coercion coexisted and were intertwined for any given working class at any given moment. Yet, the need for capitalists to utilize the coercive apparatus of states varied across national societies.

This neo-Gramscian distinction between coercive and consensual forms of labor control has indeed been taken up in the sociological literature. Yet, the general focus of the literature has been on the various mechanisms by which worker consent is achieved, be it through the technification of the labor process under advanced capitalism (Braverman 1974), the bureaucratization of management practices (Edwards 1979), changes in the labor process to global subcontracting and "just-in-time" labor arrangements (Jenkins and Leicht 1997), the globalization of labor and capital markets (Burawoy 1983; Bronfrenbrenner et al. 1998; Mazur 2000; see Silver 2003), the weakening of state sovereignty through capital mobility (Tilly 1995), the consolidation of international migratory labor networks (see Zolberg 1999: 83), and particularly of the feminization of these networks going from the global south to the global north (Sassen 1998; Ehrenreich and Hochschild 2002). With few exceptions the contemporary literature tends to underemphasize or avoid altogether an analysis of the direct use of state and/or private forms of violence to assure worker participation in capitalist labor processes. ${ }^{1}$ To be sure, the use of direct forms of state and/or private militia violence against workers has indeed dwindled throughout the latter half of the $20^{\text {th }}$ century in much of the global north, where the bulk of the historical case studies rest. Yet, this emphasis on worker consent to capitalist control contrasts sharply with the literature on contemporary political-economic transformations occurring in parts of the global south, where neoliberal state policies aimed at global economic integration have become possible through the active use of state violence, political crisis, and the direct use of military and police forces to quell the opposition (Harvey 2003; Arrighi 2007; Klein 2007).

Broadening the empirical map to examine labor regimes in peripheral regions of the world economy thus carries with it the need to broaden the conceptual map to include theories of labor regimes that vary between consensual mechanisms (changes in labor market dynamics, labor processes, state labor regulations) and coercive mechanisms (military, police, paramilitary, and private militia violence) used by capital to control labor. This being said, to simply retain the neo-Gramscian distinction between coercive and consensual labor regimes does not go far enough in capturing the full range of labor regime dynamics experienced by workers under world historical capitalism because it privileges situations under which capitalists effectively dominate workers. The example of Colombia's banana region in the 1980s and coffee region in the 1990s, however, shows us that capitalist labor regimes are highly contingent upon the capacity to contain worker militancy. Indeed, worker agency can propel crises of capitalist control over the labor process, or even propel the establishment and consolidation of alternative forms of production that exist outside of the influence of capitalists altogether. In order to capture such scenarios, I widen the neo-Gramscian conceptual framework to include three ideal-types of labor regimes, depicted in the following table:

\footnotetext{
${ }^{1}$ See Wallerstein 1974; Seidman 1994; Lee 2007; Chomsky 2008.
} 
Figure 2: Neo-Gramscian Ideal-Typical Labor Regime Dynamics

\begin{tabular}{|c|c|c|c|}
\hline \multicolumn{2}{|c|}{} & \multicolumn{2}{|c|}{ Use of State and/or Private Violence against Producer } \\
\cline { 3 - 4 } & & NO & YES \\
\hline & YE & (1) & (2) \\
S & "Hegemony" & (Coercive Domination) \\
$\begin{array}{c}\text { Effective } \\
\text { Elite } \\
\begin{array}{c}\text { Control } \\
\text { over Labor } \\
\text { Process }\end{array}\end{array}$ & NO & (Consensual Domination) & (3) \\
\cline { 2 - 4 } & & \multicolumn{2}{c}{ “Crisis of Control” } \\
\end{tabular}

The ideal-type displayed in box (1) describes a labor regime in which capitalists maintain control over the labor process (effectively manage the extraction of surplus labor from producers) without relying upon direct instances of state and/or private armed forces to assure worker participation. I call this ideal-type of labor regime, "hegemony."2 The labor regime displayed in box (2) is the ideal-typical opposite. It describes a situation in which direct instances of state and/or private armed forces are used by capitalists to assure worker participation in the labor process. I call this ideal-type of labor regime, "despotism” (or simply, "coercive domination”). ${ }^{3}$ Box (3) differs from boxes (1) and (2) in that it indicates a situation in which capitalist classes have lost their capacity to effectively control their working classes, who neither consent to nor are forced to submit to the labor process whether or not force is applied. I will call this ideal-type, a

\footnotetext{
2 The precise definition of Gramsci's definition of "hegemony," as well as how to operationalize that definition in specific research designs, is debated in the scholarly literature. The concept has become fashionable with "cultural studies" scholars who liken the concept to the cultural processes and symbolic meaning systems that create a "false consciousness" in subaltern groups and classes (see Joseph and Nugent 1994). In contrast to this conception, which explores hegemony and hegemonic projects as a strictly ideological apparatus, I understand it in a "historical materialist" wherein hegemony is established by a social grouping through its capacity to channel the activities and interests of subaltern groups, leading the system of groups and classes in a direction that inflates (rather than deflates) the power of the hegemon. For a detailed discussion of this understanding of hegemony, see Arrighi and Silver (1999).

${ }^{3}$ I use this term "despotism" in a way similar to the concept of "domination without hegemony" used by Guha (1995).
} 
"crisis of control." Using this ideal-typical conceptual framework, we see that the trajectories of the two regional cases (the "dependent variable") can be mapped as follows:

Figure 3: Trajectories of Labor Regimes in Colombia's Coffee and Banana Regions

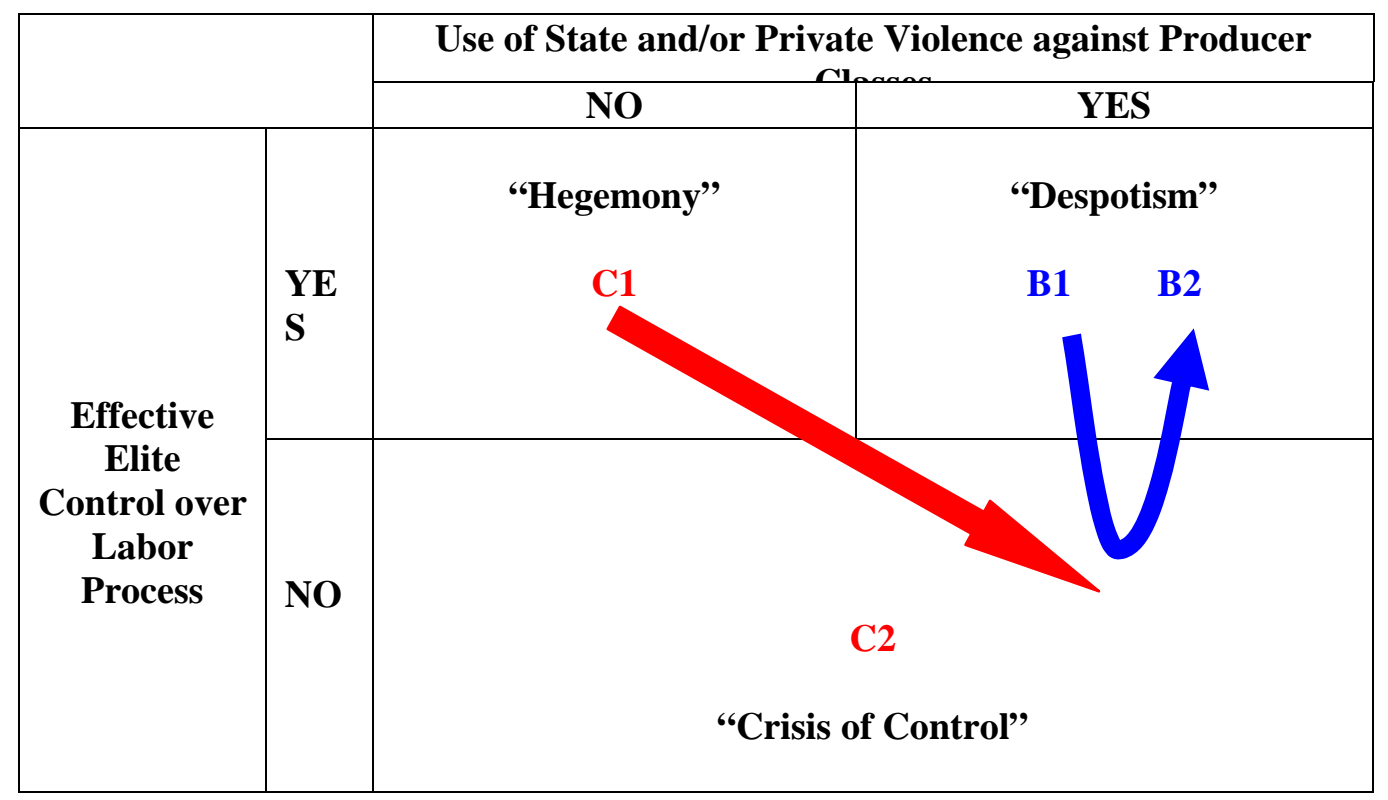

B = Banana Region of Urabá

$1=$ Postwar Developmentalist Period

C = Coffee Region of Viejo Caldas

2 = Contemporary Neoliberal Period

\section{Towards a Spatial-Temporal Theory of Labor Regimes and Commodity Chains}

As we saw from the previous section, the literature on labor regimes' tendency to focus on how hegemonic regimes are established and maintained over time leaves us ill-equipped to explain the broad spatial-temporal variation in labor regime dynamics characterizing Colombia's political economy, which include situations of hegemony, despotism and crisis. Moreover, the fact that spatial variation continues into the present (the coffee regime shifts to a 'crisis of control' while the banana regime returns to 'despotism') poses a particular challenge to those scholars who argue that the contemporary era of globalization is characterized by a general "race to the bottom" in wages and work conditions that eliminates any variation in the nationally-constituted labor regimes of the past as workers across global space compete in one global labor market (Tilly 1995; Bronfrenbrenner et al. 1998; Mazur 2000; Ross 2004; Chomsky 2008; see Silver 2003).

In order to explain Colombia's shifting labor regime trajectories, we therefore need to draw from a theoretical model that views the spatial-temporal unevenness of labor regime dynamics as a central constitute force of historical capitalism. Perhaps the most systemic 


\section{JOURNAL OF WORLD-SYSTEMS RESEARCH}

discussion of the unevenness of labor regimes across the world capitalist system was articulated by Immanuel Wallerstein. In The Modern World-System, vol. 1 (1974) Wallerstein argues that the emergence of the capitalist division of labor in $16^{\text {th }}$ century Europe gave rise to three regionallydistinct "modes of organizing labor" so as to assure capital accumulation at the world-systemic level. In "core" centers of capital accumulation of the world-economy - including "Western Europe and the Mediterranean Christian world" - the predominant form of labor control came indirectly (via market mechanism) due to the predominance of "free labor." That is, in the interests and activities of workers fell in line with the interests of capitalists due to the workers need to make a living by selling their labor power in the "free" labor market. In contrast, the predominant form of labor control in "peripheral regions" - including Eastern Europe and Hispanic America - was "forced labor" (slavery and coerced cash-crop labor). Here, workers were directly forced (via juridical/state coercion) to apply their labor power to capital accumulation. Finally, Wallerstein argues that "semi-peripheral regions" - including "former core areas turning in the direction of peripheral structures" - the predominant form of labor control was sharecropping and other "in-between" forms characterized by some mixture of market and state mechanisms of coercion (Wallerstein 1974: chapter 2).

We see elements of Wallerstein's argument that "modes of organizing labor" are spatially-patterned across the global division of labor in the work of Charles Bergquist himself. Bergquist argues that the structure of production in the coffee region, defined by smallholding farmers using family forms of labor, is the central factor buttressing the active consent generated by the coffee smallholders to the capitalist class of merchants-financiers-exporters who exploited the farmers through their monopolization of the market rather than through control over production itself. Though Bergquist did not focus his attention on forms of labor control in Colombia's banana axis in Labor in Latin America, in his later work on Colombia's protracted conflict he reiterates his argument that the hegemony of elites and "the historical weakness of the left" are to be found in the lived experience of the majority of Colombians and of the small coffee producers in specific. He writes,

If the Colombian economy had come to depend on bananas or oil exports, the twentieth-century history of the nation, and the fate of leftist third parties in particular, might have been different... But it was coffee, much of it produced by small owner-operators that became the axis of the modern Colombian economy (Bergquist 2001: 204).

This is a stimulating argument, and Wallerstein himself might therefore agree that Colombia would rightfully be categorized as a "semi-peripheral state" precisely because it contains both core-like modes of production (such as that characterizing coffee sector) as well as peripheral-like modes of production (such as that characterizing the banana sector). Yet, such a line of reasoning only creates new descriptive words rather than offer a plausible explanation for the divergent patterns themselves. One might ask, why did the structure of production remain smallholder based in the coffee economy and not in the banana economy?

Perhaps the most provocative and compelling critical reformulation of Wallerstein's thesis came from fellow world-systems scholar, Giovanni Arrighi. In contrast to Wallerstein, Arrighi argued that the key distinction between core, semi-peripheral, and peripheral positions within the modern world capitalist system was not their specific modes of organizing labor, but 


\section{LESSONS FROM COLOMBIA 132}

the rate of accumulation accruing to capitalists and states that are unevenly located across the system. Core, semi-peripheral and peripheral categories explain positions within the world's hierarchy of wealth rather than any specific type of productive activities. Drawing from Marxian and Schumpeterian ideas, he writes:

Capitalism is an evolutionary system in which the stability of the whole is premised on the perennial change in and of the parts. Core-periphery relations are no exception. The kinds of inputs, outputs, and techniques of production and distribution and the positions in networks of trade and resource allocation that endow states with differential capabilities to appropriate the benefits of the world division of labor are assumed to change continually as a consequence of the introduction and diffusion of political, economic, and social innovations... In this kind of conceptualization, what is a core and what is a peripheral mix of activities vary continually over the time and space of the world-economy... Core-periphery relations are determined not by particular mixes of activities, but by the systemic outcome of the perennial gale of creative and not-so-creative destruction engendered by the struggle over the benefits of the world division of labor. The central claim of world-systems analysis concerning the benefits of the world division of labor is determined primarily by its position, not in networks of exchanges, but in a hierarchy of wealth. The further up the hierarchy of wealth a state is, the better positioned its rulers and subjects are in the struggle for benefits. Their opportunities to initiate and control processes of innovation or to protect themselves from the negative effects of the processes of innovation initiated and controlled by others are distinctly better than the opportunities of the rulers and subjects positioned further down in the hierarchy of wealth (Arrighi 1990: 15).

Arrighi thus posited a map of the world capitalist system premised upon differing capacities of core and peripheral actors to attain wealth and exclude others from access to it. This argument is posited clearly in an article Arrighi co-authored with Jessica Drangel, where they applied this Schumpeterian logic of creative-destruction to the study of commodity chain dynamics. They agree with Hopkins and Wallerstein's (1986: 159) definition of a commodity chain as a "network of production processes whose end result is a finished product." Likewise, they believe that commodity chain locations, or "nodal points," are like boxes that contain "corelike" and "periphery-like activities," with semi-peripheral locations containing a "more or less equal mix of core-peripheral activities." Yet, they argue that these activities cannot be likened to any specific type of labor process, commodity produced, or class structure. Rather, the inequality of wealth along any given commodity chain is determined by the differing capacities of the actors located in each node (including firms and states) to externalize market competition onto the rest (Arrighi and Drangel 1986: 11-12, 16-17).

Under this schema, we see that the commodity chain itself becomes the specific site of contention between core and peripheral actors, who struggle over how to avoid market competition ("crowding”) and reap "core-like profits." The "weapon of competition," they argue, is therefore "the ability to shift continuously the pressure of competition from one's organizational domain onto activities that fall outside that domain.” Moreover, at any given 
moment in time, the wealth generated along each commodity chain is finite and that the struggle over access to this wealth is a "zero-sum game.” By definition, commodity chains under historical capitalism are thus constituted by a structural contradiction wherein moving up from lower to higher nodes along a chain ("upgrading") must entail the movement down a chain ("downgrading”), without a simultaneous expansion (or contraction) of the system as a whole (Arrighi and Drangel 1986: 18-23, 27-28).

Arrighi uses his own theories to examine the world historical transformations in this systemic expansion and contraction, or the systemic cycles of accumulation that characterize world systemic hegemonies. And to be clear, Arrighi himself argues that core-periphery locations along a commodity chain do not pre-determine the types of labor processes, commodities produced, or systems of production and exchange that will exist in core or peripheral locations (Arrighi and Piselli 1987; Arrighi 1990 and 1994). Yet, there are strong implications that such world-systemic conditions would have an impact on labor regime types at the local level. For instance, in his work on the rise and fall of global hegemonies, Arrighi does indeed argue that global hegemony is established through the capacity for the hegemon to lead the system of states and firms in a way that turns competition in the world market in a direction that expands the material wealth of the system as a whole. In contrast, hegemonic decline occurs when the institutional and structural arrangements buttressing the material expansion of the system turns give way to a form of competition that undermines the power of the hegemon. Moreover, we find a similar world-systemic logic in the work of Silver and Slater (1999), who explicitly argue that there is a direct causal relationship between variations in consensual-coercive forms of class rule across time and phases of world hegemony, with periods of hegemony being characterized by a tendency towards the prevalence of consent and periods of hegemonic crisis and breakdown characterized by a greater prevalence of coercion.

Implicit then in Arrighi's theoretical model is a spatial theory of forms of labor control. That is, drawing from Arrighi's theory of the structural nature of global commodity chains we can formulate a set of hypotheses relating variation local labor regime types to core-periphery locations along the commodity chains that constitute the modern world-system. Hegemonic labor regimes will tend to exist in commodity chain locations characterized by "core-like activities" because the capitalists of that node accumulate enough capital to invest in both further capital accumulation processes as well as in the establishment of a hegemonic pact vis-à-vis the laboring population. Likewise, despotic labor regimes will tend to exist in commodity chain locations characterized by "periphery-like activities" because the capitalists of that node are faced with intense market competition and therefore do not accumulate enough wealth to invest in both a hegemonic project as well as further capital accumulation processes. But can this proposition help explain the divergent forms of labor control in the coffee and banana nodes of Colombia?

\section{THE SPATIAL PUZZLE: DIVERGENT LABOR REGIMES OVER SPACE}

\section{Explaining Hegemony in the Coffee Region}

Though coffee production for export in Colombia dates back to at least the 1820s, it did not become a primary export commodity until the $20^{\text {th }}$ century. And even then, one cannot speak of anything close to a hegemonic labor regime constituting the coffee sector until at least the late 


\section{LESSONS FROM COLOMBIA 134}

1930s and early 1940s, following a wave of coffee producer militancy that led to the transformation of the structure of the sector from one based predominantly upon semiproletarianized and proletarianized labor systems to one based predominantly upon a smallholding farmer structure of production. According to Bergquist (1986), it was this structure of production and the "lived experiences" of the coffee smallholding farmers who constituted this mode of production that laid the structural backdrop for the rise and persistence of a hegemonic labor regime over the course of the subsequent decades. Yet, contrary to Bergquist, we shall see that this smallholding structure of production depended in important ways on the agency of the sector's mercantile elites (and backed by the central government) to invest in its expansion and persistence. Moreover, the success of these elites in stabilizing the local coffee sector by investing in a hegemonic form of labor control was premised upon their success in taking advantage of the world historical moment to "upgrade" from a peripheral to a core nodal location along the global coffee chain.

Though the wave of militancy of the 1920s and 1930s forced the sector's largest landowners to abandon and/or sell off their coffee lands to the mass of former tenant farmers, workers, and marginalized coffee farmers who had been victorious in their struggles for that land, the sector itself was left with a number of major economic, technical and social problems that could not be solved solely by the smallholders themselves. These problems included the sector's long-term declining terms of trade in the international market as well as the growing influence of usurious merchants over local transportation routes and market activity, the latter of which contributed to unstable flows of beans from smallholders to international markets, a deterioration in the quality of beans exported, and the frequent indebtedness and financial vulnerability of smallholders. It was the formation of the National Federation of Coffee Growers of Colombia (Fedecafé), a private association of coffee financiers, marketers, and exporters who were granted with a public mandate by the Colombian government to regulate and organize the sector, that we see the consolidation of a consensual form of labor control in the coffee axis region. Fedecafé immediately set out to rectify these problems associated with the sector. Two sets of issues were addressed: technical-economic and social-political. In terms of technical-economic problems, the first thing Fedecafé did was establish their monopoly over the purchase of locally-grown coffee. They began directly purchasing from coffee smallholders who, due to the sparse nature of smallholds, had been susceptible to usurious merchants who purchased smallholder beans for very little and sold them to exporting firms for very much. Fedecafé built storage houses (trilladoras) spread diffusely throughout the coffee axis region so that smallholders could sell their beans directly to Fedecafé itself. Not only did this eliminate the transport costs and usurious middlemen, they implemented "guaranteed purchase" policy so long as the beans brought to their trilladoras met certain quality standards. The result was not only stable and cheaper coffee bean supplies, but the incentive structure for the smallholders themselves to oversee the quality of the coffee beans they cultivated (London 1995: 5-6).

Though smallholders were granted a guaranteed purchase, this did not by itself offer them the incentive to produce more coffee and less staple foods on their smallholds. Central to the establishment of Fedecafé's hegemonic control over the region came through the establishment of the National Coffee Fund (FNC) in 1940. The FNC was the mechanism by which Fedecafé collected taxes upon all coffee beans exported and utilized those revenues to reinvest these surpluses in Fedecafé institutions and policies. Thus, FNC revenues translated into a "price floor” policy so that coffee smallholders did not only have a guaranteed market for the beans they 
cultivated. They were also guaranteed a price that buffered against a direct impact of global fluctuations on local markets by subsidizing farmers during economic busts. This assured smallholders a certain degree of confidence in converting the bulk of their smallholds into coffee fields without worrying about making up for busts in coffee prices by increasing yields, as they had done beforehand. In other words, it helped regulate against periodic crises of overproduction that had previously characterized the coffee market.

While the creation of trilladoras, guaranteed purchases, price floors, and the FNC itself were effective in correcting some of the technical and economic issues previously facing the sector, in effect they allowed Fedecafé's administrators to simply consolidate their control over the lowest rungs of the global coffee market. Their interventions in the market were financed by a boom of the global coffee market during and immediately following World War II. And, though the market did indeed fluctuate, the general trend during this period was towards higher coffee prices (as seen in Figure 7 in Appendix). Thus more money poured into the FNC, and the FNC was able to use these funds to not only maintain the smallholder form of production. During this period they were able to establish a scientific institute (Cenicafe) to develop new production techniques, increase production yields, and (later on) develop anti-fungus solutions to coffee pests and fungi., as well as finance the establishment of the Banco Cafetero (to provide loans to smallholders) and finance local infrastructural developments (including roads, bridges, schools, hospitals).

Fedecafé was able finance these investments, and therefore stabilize the smallholder structure of production, by taking advantage of the temporary dislocation of Brazil's coffee export sector during the 1930s, allowing them a greater share of the world coffee market precisely during the peak boom in international coffee prices during the World War. Yet, the stability of this labor regime arrangement at the local level was premised upon the boom. And, Fedecafé was acutely aware of their market vulnerability, as well as the fact that the historical memory of the agrarian struggles remained fresh in the minds of the smallholders. Any long-term drop in coffee prices or increase in competitive market pressures could not be pushed downwards onto the backs of the smallholders without fundamentally dismantling their regulatory interventions or triggering a worker backlash. In other words, their capacity to accumulate core-like profits was indeed a temporary one. The structural reality was that they remained in a peripheral node along the coffee commodity chain, that the coffee market itself was prone violent price fluctuations due to periodic "crises of overproduction" that made local forms of regulatory market control difficult to maintain, and that the greatest profits along the chain accrued to the coffee roasters, marketers and distributors located in consumer countries rather to producers such as themselves (Bates 1997; Talbot 2004).

The "solution" to this problem of maintaining the stable reproduction of the smallholder structure of production while simultaneously maintaining (and expanding) their profitability was achieved through Fedecafé's ability to exploit the geopolitical climate of the times, and the hegemonic aspiration of the United States in particular, by advocating political alliance building across coffee exporter countries in order to restructure the world market to their favor. That is, following the Great Depression and into the years of Second World War, Latin America was undergoing a general wave of labor militancy and economic nationalism with strong antiimperialist sentiments that was threatening to undermine the hegemony that the United States had established over the hemisphere dating back to the writing of the "Monroe Doctrine." The region's political and economic elites began to openly critique the viability of the so-called "self- 


\section{LESSONS FROM COLOMBIA 136}

regulating markets” that had been the dominant economic ideology prior to the Depression. And, they were acutely aware of the structural limitations bearing on their potential for national economic growth given their position with the international division of labor as exporters of primary producers and tropical agricultural commodities (Cardoso and Faletto 1979; McMichael 2000).

It was in this geopolitical context that Fedecafé began lobbying the Colombian government to establish political alliances with other coffee exporting countries in Latin America with the overall goal of establishing a "cartel" to force economic concessions from the United States. As John Talbot notes, the first attempt at this type of "collective action strategy" by Latin American coffee exporters came during the War itself, when the U.S. proposed an "InterAmerican Coffee Agreement" that set import quotas on coffee coming into the U.S. market that guaranteed exporters both a large market share as well as favorable coffee prices for their exports. In fact, it was this first agreement that formed the institutional basis for Fedecafé's capacity to reap core-like profits in the first place. Yet, when the war ended so did the IAC Agreement; and the U.S. responded immediately by advocating trade liberalization policies through the "General Agreement on Tariffs and Trade" rounds in 1947. By this time, however, a second movement to fundamentally restructure the global coffee market was well underway. In 1959-1960, the first International Coffee Agreement (ICA), including 94\% of the world's coffee exporters, was signed wherein exporters themselves established quotas on shares of the global market, and prices were determined by the bloc of exporters themselves (who would collectively withhold coffee from the market in order to drive prices up). However, even this first ICA failed to function primarily because it lacked an effective vehicle to enforce adherence to the quotas and regulate the pricing of the overall system (Krasner 1973; Bates 1997: 90-92; Talbot 2004: 49, 58).

The tide turned in favor of the ICA producers as U.S. foreign policy towards Latin American changed in the aftermath of the Cuban Revolution. Through the "Alliance for Progress" initiatives, the Kennedy Administration began to favor the promotion of "economic stability" (though economic and military aid and trade policy initiatives) rather than the promotion of liberal policies. The ICA countries immediately offered to extend the agreement to the U.S., wherein the U.S. would accept the quotas and pricing of the ICA countries and enforce the overall pricing system, and a new agreement was signed in 1962. New agreements were re-ratified periodically thereafter, lasting until 1989. While some debate exists over the actual distribution of power among ICA producer and consumer countries, the general result of its establishment was the institutionalization of stable and highly profitable market niches for key exporting countries, including Brazil and Colombia, who collectively garnered almost $50 \%$ of the world market by the end of the decade (Stewart 1992: 245; Bates 1997: 120-121; Robledo 1998; Talbot 2004: 40).

The creation of the ICA had favorable, long-lasting implications for the future profitability of Colombia's coffee sector and for the stable reproduction of the hegemonic labor regime at the local level. Foremost among indicators of local level hegemony is the degree to which coffee farmers identified with the elite-led Liberal and Conservative political parties that had dominated Colombia's political system since the $19^{\text {th }}$ century. It is widely pointed out that this adherence to party loyalties rather than class-based identities was a driving factor behind the outbreak of La Violencia (1947-1957), a period of brutal partisan warfare that led to the killing of some 180-300,000 civilians by its end. Moreover, as many regional studies of La Violencia have shown, the warfare remained politically-sectarian in nature in coffee producing regions alone. 
Elsewhere, the warfare tended to transform over time into local-level class conflicts (Bergquist 1986: 276, 368; Ortiz Sarmiento 1992: 126-127; Roldán 2002; Livingstone 2004).

A second indication of the degree to which coffee producers identified with the interests of Fedecafé is evidenced by their ardent support of the formation of the "National Front" regime in 1957 (which brought La Violencia to an end), a power-sharing agreement between the Liberal and Conservative parties which formerly excluded third parties from office and appointed locallevel political position directly by party leaders rather than allow popular municipal and governmental elections. Fedecafé and the coffee electorate itself were powerful advocates of this regime. Interestingly, when the exclusionary nature of the National Front regime itself sparked a number of agrarian revolts in the early 1970s and later guerrilla groups by the late 1970s and 1980s, such agrarian movements and guerrilla groups could never gain much traction in the coffee axis region of Viejo Caldas, which remained a clientelistic stronghold of the traditional Liberal and Conservative parties (Gilhodes, 1972; Ocquist, 1978: 16-19; Zamosc, 1986: 140; Ortiz, 1999: 36).

Finally, we see that Fedecafé was able to assert its hegemony even beyond the material interests of the coffee producers themselves. That is, we see that Fedecafé (through Cenicafe) were able to convince coffee farmers to wholeheartedly adopt scientific techniques and methods of production that required costly fertilizers, new varieties of trees, and steady access to credit to finance such investments. This transformation towards "industrial" coffee farming techniques increased the productivity of the sector and the volume of exports going to international markets, which had direct bearings on Fedecafé's profitability. Yet, the technification of coffee farmlands meant that the livelihood of the smallholders themselves was becoming increasingly monetized, thus undermining their self-sufficiency and making them evermore dependent upon Fedecafé institutions for their sustenance, which, as we shall see, would have grave political implications in the absence of Fedecafé oversight of the sector (London 1999).

\section{Explaining Despotism in the Banana Region}

The formation of Colombia's banana sector in Urabá cannot be understood outside the historical context of contentious relations associated with the global banana industry. Since the turn of the $20^{\text {th }}$ century, the predominant market for Latin American bananas was the United States and the primary recipient of banana profits was the United Fruit Company (UFC). In fact, the UFC's monopoly rested upon its vertical integration of the global banana industry, which stretched from its ownership of banana plantations, its control over local and international trade routes, and its dominance over the marketing and distribution channels in consumer countries. Yet, the UFC's landholdings and business practices became particularly controversial throughout Latin America during the wave of militant nationalism and anti-imperialism from the years of the Great Depression to the Second World War. In Colombia, the UFC had established its own plantations in the Santa Marta region, a few hundred miles north of Urabá along the Atlantic Coast. Throughout the late 1920s, banana workers on the UFC's plantations organized a number of powerful strikes that ultimately led to a massacre of banana workers in 1928 by the Conservativebacked government. This massacre, famously depicted in Gabriel Garcia Marquez' novel One Hundred Years of Solitude, helped delegitimize the Conservative regime, eventually leading to the election of the Liberal Party in 1930, whose unwillingness to use force against banana worker 


\section{LESSONS FROM COLOMBIA 138}

militancy was a primary reason behind the pull-out of the UFC from the region by 1934-35 (LeGrand 2003: 204; Bucheli 2005: chapter 5).

The labor militancy and violent repression that occurred in Santa Marta was, in fact, typical of a more general trend affecting the United Fruit Company's plantations throughout Latin America. And by the 1950s, animosity against the UFC posed a threat to US hemispheric hegemony. As we saw from the previous section, when faced with growing frustrations by coffee exporters at the time, the US was willing to sacrifice the profitability of its coffee importer and roaster corporations in order to assure its larger geopolitical legitimacy by agreeing to sign onto the International Coffee Agreements. A similar dynamic occurred in the banana sector. Rather than rely upon direct US military actions to suppress worker militancy and unfavorable terms of trade, the UFC shifted its organizational structure away from a vertically-integrated system where they monopolized transport, administered the plantations, and owned the banana-producing lands and towards the implementation of a new policy of "vertical-disintegration" where they sold off their land holdings and "externalized" the costs and risks of administering the plantations onto local plantation owners. As Marcelo Bucheli (2005) points out, this strategy of vertical integration was not driven by immediate economic concerns. Rather, it was a less-profitable organizational arrangement than the vertically-integrated system before it, but it was an arrangement that was calculated based upon long-term geopolitical as well as economic concerns. In other words, both the coffee and banana commodity chains were dramatically reconfigured in the aftermath of the Second World War in order to assure US hegemony at large. The key difference between the two transformations, however, was that the UFC's vertical disintegration strategy led to the movement of local Latin American banana capitalists into the banana commodity chain by becoming owners of banana plantations (the lowest nodes along the chain). In contrast, the formation of the International Coffee Agreement's coffee quota system led to the movement of coffee exporters up the commodity chain, from peripheral to core-like nodes.

In Colombia, the United Fruit Company's organizational transformation had a direct bearing on the establishment of a new banana-export enclave in the Urabá region in the early 1960s. In fact, the National Front regime inherited the developmentalist aspirations lingering from the prior period of economic nationalism, and saw the opportunity to move into the banana sector as planter-exporters chance to stimulate its export-promotion and diversification development strategy. As such, the Colombian state itself helped local elites to finance the purchase of large tracts of Urabá's land as well as transport routes and other investments needed to establish banana plantations in the region. These initiatives were successful in creating a banana export sector that was competitive in the global market as well as in consolidating a class of local elites who came to dominate local economic and political policy. Moreover, Urabá's nascent banana planters quickly established their own planter organization (akin to Fedecafé) to lobby the central government and to create an institutional forum to formulate and debate their class interests. This organization came to be known as the Association of Cattle Ranchers and Banana Producers of Urabá (or, Augura), which encapsulated the political and economic interests of both banana plantation owners as well as the class of cattle ranchers who monopolized landholdings in the regions immediately surrounding the plantations (Botero Herrera 1990: 100101; Bucheli 2003: 174).

Labor relations on the plantations, however, were contentious from the beginning. First, wage workers were drawn from nearby rural frontier regions, where they were being evicted from lands by large-scale cattle ranchers and landed elites, those same individuals who actively 
participated in formulating Augura's policy initiatives. Moreover, the actual wages and working conditions were dire. ${ }^{4}$ Second, since the Liberal and Conservative parties monopolized the political system (thereby excluding third parties that advocated class-based policies that would represent the interests of banana workers), the primary channel to express worker interests came through attempts to form worker unions. Third, it is well-documents in the literature that these early attempts to establish worker unions in Urabá were systematically subject to military and other forms of elite repression in the 1960s and 1970s. Sintrabanano (a group affiliated with the nascent labor federation of the Colombian Communist Party, PCC), Sintagro (a group originating from the Conservative Party-affiliated Union of Colombian Workers, UTC) and later adopting Maoist-leanings, and Sintraexpoban (also affiliated with the UTC) all attempted to establish unions on Urabá's banana plantations only to be subject to direct military violence and military occupations of banana plantations. The only union to survive the period was Sindejornaleros (a group affiliated with the Revolutionary and Independent Workers Party, MOIR), though it remained marginal in its efforts to unionize plantations. In fact, it was noted that an estimated $46 \%$ of Urabá's plantations did indeed have formal labor agreements established by the end of the 1970 s. Yet, only $77 \%$ of those agreements were imposed by employers on unfavorable terms to workers. A mere $11 \%$ of all labor agreements were actually negotiated between workers and employers (Botero Herrera 1990: 156-58; Carroll 2000: 152-153). Given this exclusive and repressive political context, and the direct repression of worker militancy on the plantations, it is no wonder that the Revolutionary Armed Forces of Colombia (FARC) and Popular Liberation Army (EPL) guerrilla groups found backing from the region's banana workers.

Though effective in containing labor militancy, this despotic labor regime established in Urabá was not necessarily ideal from their perspective either. In fact, one year after the success of OPEC in raising oil rents, and witnessing the success of the ICA system for the coffee sector, Augura along with other key Latin American banana planter-exporters (including Costa Rica, Guatemala, Honduras and Panama) began their own "collective action" strategy with the goal of fundamentally restructuring the distribution of profits in the world banana market to their favor. In 1974, they signed the "Panama Agreement" to increase taxation on banana transnational corporations operating in their territories, modify the tax and land concessions previously granted to them, and manipulate exports in order to raise the international banana market prices. After a period of intense diplomatic conflict between the producers and the largest banana transnational (including United Brands, formerly the UFC), a settlement was reached that formally established the Union of Banana Exporting Countries (UBEC).

The UBEC's first and most important success was its capacity to reestablish tax and land concessions granted to foreign banana corporations on Latin American soil. From our perspective, however, we can see that these efforts to grant greater freedom to local capitalists to establish their own plantations was essentially a continuation of, rather than fundamental break with, the vertical disintegration processes initiated by the United Fruit Company almost two decades before it. The difference was that the UFC no longer monopolized the market, so that local land holdings and contracts were renegotiated with the whole gamut of banana transnationals operating in Central and South America, including the Dole and Del Monte

\footnotetext{
${ }^{4}$ Leah Carroll notes that by 1979, an estimated $80 \%$ of workers lived directly in work camps located on the plantations they worked at. Only $6.6 \%$ of these camps had access to running water, $33 \%$ contained latrines, and 50\% had no electricity (Carroll 2000: 147, 155-156, 167).
} 


\section{LESSONS FROM COLOMBIA 140}

corporations. And while this movement into the bottom rungs of the global banana commodity chain was indeed a form of upgrading for those previously excluded from the chain, it did not constitute an upgrade for Colombia's banana planters who had already occupied this position with the original establishment of domestic banana plantations in Urabá in the early 1960s. Consequently, this movement of a new group of producers into the banana chain actually further crowded the banana producer market rather than ameliorate the competition associated with that node along the chain.

To be sure, the UBEC recognized the necessity to institute a more fundamental restructuring of the chain in order to redistribute world banana market profits. Yet, it was least successful on precisely this terrain. Though a detailed account of the failure of the UBEC to establish a quota and pricing system does not exist in the literature, we can see a number of structural obstacles the UBEC faced that did not face the coffee producers of the ICA. First, while the ICA of 1961 included $94 \%$ of the world's coffee producers, the UBEC only included $42.9 \%$ in 1974 and only reached 50\% by 1982. Thus, banana producers outside of the UBEC began to use their outsider's status in order to prop favorable trade agreements with banana importers to the detriment of UBEC countries. A second reason has to do with the nature of the importers themselves. While the US imported $62.8 \%$ of the world's coffee market at the time of the signing of the ICA in 1961, it only imported 26.8\% of the world's banana market in 1974 (Talbot 2004). Thus, lacking a central enforcement mechanism that could penalize those countries who over- and under-supplied the global banana market (as the U.S. had done for the ICA), the UBEC's capacity to manipulate and regulate world prices remained structurally powerless and insignificant. Third, the difference in timing was a key factor in the structural weakness of the UBEC. That is, the formation of the ICA occurred precisely at a moment of militant nationalism and anti-imperialism at the world-systemic level, when the world's largest importer (the U.S.) was establishing itself as the dominant hegemonic power internationally. It was therefore willing to sacrifice immediate economic profits for global political legitimacy. By the late 1970s, however, the question of profits was beginning to trump concerns about global political legitimacy and fears of social revolution and militant nationalism globally. Thus, not only was the U.S. in a structurally weaker position in the banana market relative to the coffee market. It was also less willing to adopt the favorable types of international trade measures that it had adopted in the 1960s.

In fact, the UBEC's collective action strategies in general proved to be short-lived. By the turn of the decade, the state-led marketing firms that moved into the producer-nodes in Central American countries following the formation of the UBEC began to lower their export taxes and once again establish incentives to attract foreign banana conglomerates. Moreover, by then the predominant characteristic of the global banana trade was not its organizational division between politically-aligned producer countries pitted against consumer countries (as was the case of the global coffee market). Rather, the global banana market was structurally divided between a "dollar market” linking Latin American banana producers to the U.S. market and institutionalized under "liberal" trade rules and an "APC market" linking former European colonies located in Asian, the Pacific and the Caribbean to the European market and institutionalized under "regulated" trade rules that granted exporters favorable quotas and price floors (FAO 1986: 3, 68; Raynolds 2003: 30, 38-39).

We see that Colombia's banana capitalists were indeed stuck within a peripheral node along the banana commodity chain, which was governed by liberal trade rules and characterized by market competition and limited profits. And given the crowding of this node, Colombia fought 
tooth and nail to remain competitive by keeping their production costs low. In practice this meant that their capacity to stay afloat in the banana market was premised upon their capacity to effectively repress banana worker demands for a greater redistribution of the profits made. Any attempts to organize for more favorable concessions from Urabá's capitalists directly threatened their market position, which explains the intransigence and propensity of Augura and their allies to call in the military to violently and forcibly maintain their control over the local political economy.

In summary, we see that in both cases we find evidence to support the world-systems hypothesis that labor regime dynamics are indeed affected by one's location along a commodity chain. The hegemonic regime characterizing Colombia's coffee region in the postwar decades was premised upon the successful upgrading of Fedecafé from a peripheral to a core-like node along the chain. In contrast, the despotic regime characterizing Colombia's banana region was premised upon the need to maintain profitability within the peripheral node of the banana chain.

\section{THE TEMPORAL PUZZLE: LABOR REGIMES TRANSFORMATION OVER TIME}

In the previous section of this paper, we found evidence in support of the "spatial hypothesis" drawn from world-systems analysis. That is, the formation of a consensual form of domination in the coffee region was the product of the coffee capitalist class' capacity to upgrade from a peripheral to a core-like position along the global coffee commodity chain and therefore use its core-like profits to invest in both capital accumulation as well as in a local-level hegemonic project that incorporated the coffee producer class as a junior partner. In contrast, the inability for Urabá's banana capitalists under Augura to upgrade into a core-like position along the banana commodity chain forced them into a structurally crowded position. Their capacity to maintain this peripheral, competitive node came from their capacity to push market pressures downwards onto the backs of workers through the repression of banana unions at the point of production and the exclusion of working-class parties from access to local-level political positions.

However, these apparently stable though distinct forms of labor control both broke down in the 1980s and 1990s. By the mid-1980s, Urabá's banana workers were able to break the repressive stronghold of local elites and effectively organize unions on the plantations and elect local politicians who expressed their class interests, despite drastic increases in reactionary violence from local elites. It was only until the mid-1990s that the banana planters were able to reestablish a coercive form of domination once again. This rise and dramatic fall in worker militancy (including strikes, marches, and demonstrations), and its relation to the rise in incidents of state and paramilitary repression (including death threats, assassinations, and massacres), is evident in Figure 4 below. 


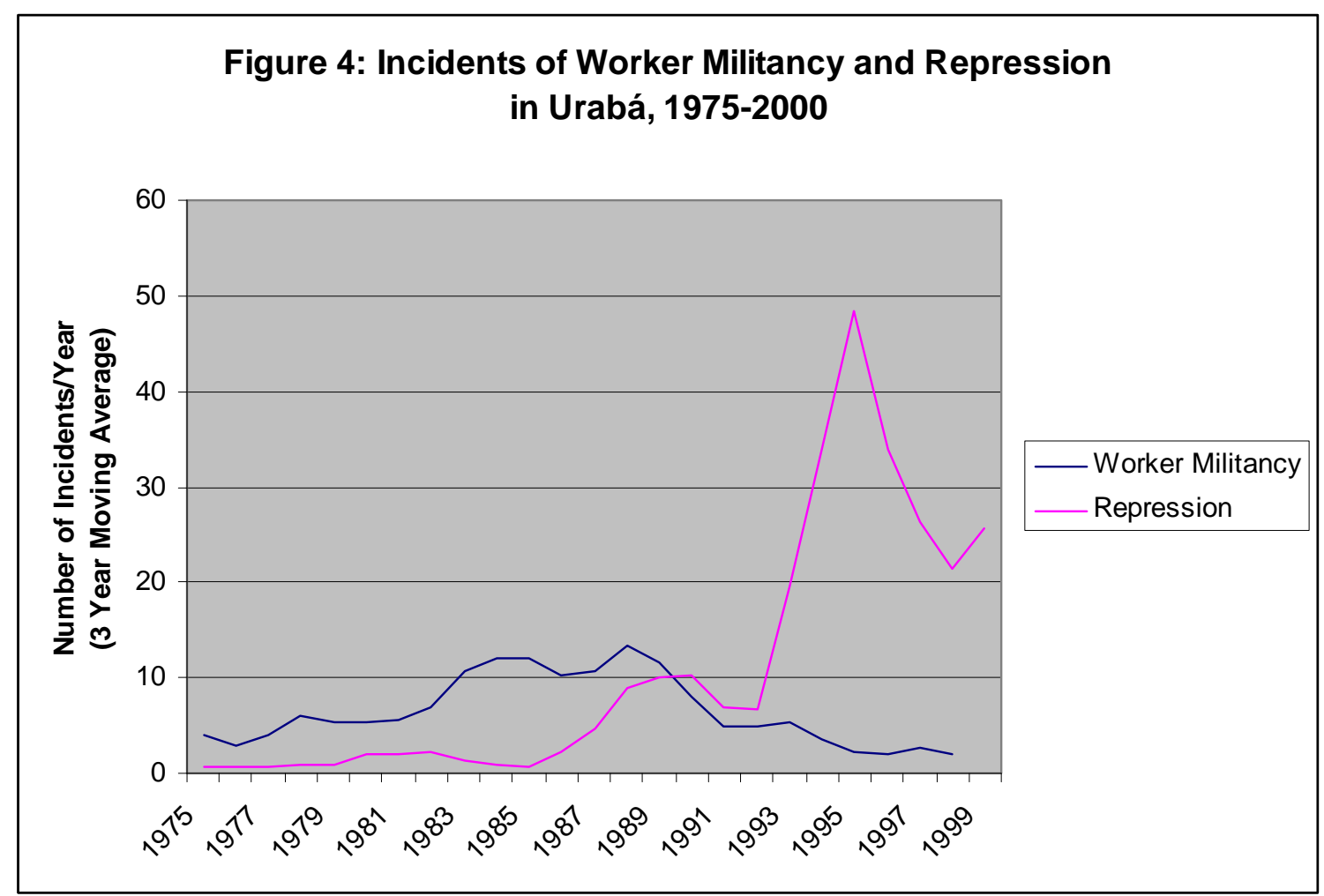

Sources: CINEP (Social Movement Database); CINEP (Banco de Datos); El Tiempo. ${ }^{5}$

In the coffee axis region of Viejo Caldas a similar pattern emerged. As mentioned, before then the region remained impervious to working-class social movement and political activity due to the effectiveness of Fedecafé's hegemonic project at the local level. Yet, by the mid-1990s Fedecafé hegemony had unraveled, giving way to a growth in social conflicts including guerrilla activity and powerful social movements, also despite an eruption of elite repression. This growth in both social protest activity (including strikes, marches, and street demonstrations related to the coffee sector) despite the rise in incidents of state and paramilitary repression (including death threats, assassinations, and massacres), is evident in Figure 5 below.

\footnotetext{
${ }^{5}$ The incidents of "worker militancy" (defined as strikes, marches and street demonstrations occurring in the region) were compiled using Colombian newspaper sources by the "Social Movement Study Group" of the Center for Investigation and Popular Education (CINEP) based out of Bogota. Its findings are published in Archila et al. (2002). The incidents of "repression" (defined as death threats, assassinations, and massacres occurring in the region) that occurred between 1987 and 2003 was also compiled by CINEP using newspaper sources. The author replicated their data analysis, extending the newspaper reports from 1975 to 1987. For an extensive discussion of the datasets used see Hough (2007).
} 


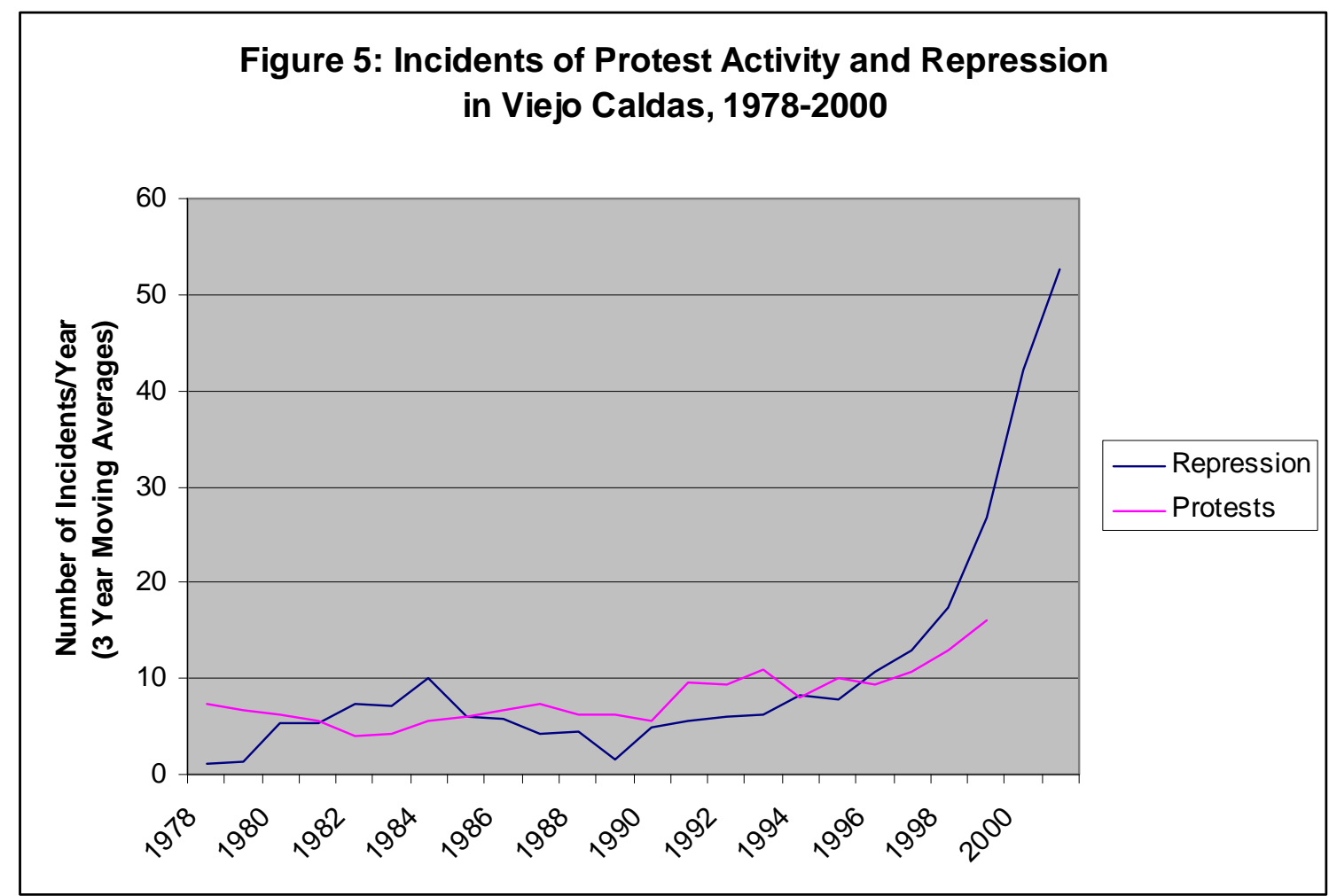

Sources: CINEP (Social Movement Database); CINEP (Banco de Datos); El Tiempo. ${ }^{6}$

Both regions underwent a "crisis of control" situation characterized by an inability of local elites to effectively repress social protest activity and militancy from the local working classes and subaltern groups. But why did these breakdowns occur? How can we explain the shift in forms of labor control in the same regions over time? The theoretical model utilized previously to explain spatially-distinct forms of labor control would relate these shifts to some type of transformation in the positioning of each sector's activities along their respective commodity chains. But is this true? Was the temporal shift in forms of labor control caused by a shift in location along each commodity chain? And if so, does the similarity in the timing of each shift reflect a response to some larger global transformation impacting both coffee and banana commodity chains?

\section{From Hegemony to a Crisis of Control in the Coffee Region}

For those familiar with Colombia's political-economy, the most striking aspect regarding the shift in forms of labor control characterizing Viejo Caldas is not that it happened at all, but that it happened over a decade after a similar shift in forms of labor control had shifted in the rest of the

\footnotetext{
${ }^{6}$ The incidents of "protest activity" (defined as strikes, marches and street demonstrations occurring in the region and that are related to the coffee economy) were compiled by the CINEP social movement group using Colombian newspaper sources. For an explanation of the data sources see footnote 6.
} 


\section{LESSONS FROM COLOMBIA 144}

country. While the shift in the coffee axis occurred in the mid-1990s, the national shift began in the early 1980s. Let us breakdown our initial question into two sub-questions: Why the difference in timing? And why the shift at all?

Regarding the first, there is general agreement in the Colombian literature that the emergence of the crisis of control at the national level dates back to the legitimacy crisis of the National Front regime in the late 1970s. The contradictions of its policy of maintaining a repressive and exclusive political system while simultaneously implementing policies promoting rapid capitalist development had given rise to powerful social movements in the 1970s. And by the 1980s the wave of repression that these movements faced gave birth to new guerrilla insurgency groups (M-19, Quintín Lamé) and new impetus to older guerrilla insurgency groups (FARC, ELN, EPL). Popular frustration with the increasingly repressive responses to this social movement and guerrilla activity by the Turbay Administration (1978-1982) was the principal reason for the election of the reform-minded, though Conservative Party candidate, Belisario Betancur in 1982. Upon his election, Betancur ushered in a series of political reforms and peace negotiation strategies with guerrilla groups in an effort to democratize the political system and encourage greater popular participation in governmental decision-making. This period of “democratic opening" was continued under the administration of Virgilio Barco (1986-1990), culminating in the formation of a popular Constituent Assembly in 1990 and the rewriting of the Colombian Constitution in 1991 (Chernick 1991; Sánchez 2001).

Throughout this period of upheaval and democratic transformation, labor relations in the coffee region remained passive and stable. Though some social protest activity arose in the urban centers of the region (Pereira, Armenia, Manizales), the only movement activity stemming from the coffee farmers came in 1984-85, when a coffee fungus (la roya) spread through the region and the smallholders organized to force Fedecafé to 'fulfill its promises" of finding a solution to the crisis. In other words, such a movement only reflected the degree to which the farmers identified with the paternalistic policies of Fedecafé (London 1995 and 1997; Robledo 1998: 33). In fact, the eruption of powerful labor and social class conflicts and elite repression in the coffee region appears to be uncorrelated with the democratization of the regime. So what explains the (late) timing of the shift in class relations in the coffee region? It is my contention that this shift is best explained by the abrogation of the International Coffee Agreement quota system in 1989. As we saw, the ICA quota system was an institutional mechanism that guaranteed high and stable prices for coffee circulating in the global market. For Fedecafé, the durability of the ICA thus buttressed their capacity to finance their hegemonic project vis-à-vis coffee producers at the local level. Once the ICA system unraveled at the global level so too did Fedecafé's hegemonic labor regime in Viejo Caldas.

Immediately following the abrogation of the ICA in 1989, global coffee prices plummeted (as seen in Figure 4 below). By 1993, the average real indicator price for coffee greens has only $42 \%$ of what it had been during the final years of the ICA (Ponte 2001: 11-13). Fedecafé responded to this crisis by cutting its export taxes in 1990-1991 and using its accumulated reserves in the FNC to subsidize growers for losses. To make matters worse, during this period the region's coffee fields grew susceptible to a coffee berry borer worm (broca), which sparked growers to demand for loans to cover the estimated $10-15 \%$ of the total costs of production they were losing (Robledo 1998: 21-23). With lower export taxes and less revenues, Fedecafé felt forced to lower its price floors to growers and cut back on the services they provided in order to finance loans. In 1993, they sold their interests in the Banco Cafetero, 
thereby converting the bank from a semi-public bank with a mandate to service the needs of growers into a regular private bank unwilling to risk loans without asking high interest rates in return. Moreover, by the middle of the decade, the FNC was beginning to feel the crunch, as it incurred a debt of US\$433.5 million by 1997 . By 2001, facing a loss of a total of $80 \%$ of its revenues, it abandoned its price floor mechanism altogether (CONPES 2004: 13). This unraveling of Fedecafé financial and market institutions reflects their incapacity to both reinvest in capital accumulation as well as a hegemonic pact with their producers - a structural position defining peripheral rather than core-positions along a commodity chain.

The impact of this unraveling on their hegemony at the local level was immediate. Facing bankruptcy, farmers were forced to make a number of unfavorable choices. One option was to simply sell their land. In fact, by 1997 the "popularity" of this decision was becoming reflected in a rapid concentration of land holdings in the region (Ramirez et al. 2002: 50-51). Some of the lands sold went to larger coffee farmers who began to hire former smallholders as proletarian wage-workers, reflecting a polarization of the class structure (Robledo 1998). Some of those farmers who sold their land simply migrated to the regions urban centers to look for work (Ramirez et al. 2002: 41). Others left the region altogether, migrating to the coca-producing regions of southern Colombia, where they could sustain themselves under the protection of the FARC guerrillas who controlled the area. A second option was to actually convert their coffee fields into coca and opium fields. This conversion from legal to illegal economic activities threw such farmers directly in the radar of the government, whose drug-war policies often forced these farmers to look for protection by the guerrillas right there in the former coffee-producing region itself. Thus, by the middle 1990s, not only did we see a newfound ideological affinity with the guerrillas from former coffee smallholders, but we also saw the growth of a mutual dependence between them wherein guerrillas offered protection services for growers in response for a tax imposed on producers that would help finance their military and organization needs (Oxfam 2003; Richani 2002: 68-69). A third option of indebted coffee farmers was to begin organizing their own political organizations autonomous from the organizational channels provided by Fedecafé, reflected by the establishment of Unidad Cafetera Nacional (UCN) in 1992, their national coffee shutdown strikes in 1995 and 1997, and their fusion into the National Association for Agricultural Salvation organization (an anti-FTAA agricultural producers association) by the end of the decade (Robledo 1998: 38-42).

In short, by the middle of the 1990s, the region's capital-labor relations had felt the impact of the "downgrading' of Fedecafé along the global coffee commodity chain. But how can we explain that shift in location? Why was the ICA abrogated in 1989? Was this shift reflective of a simple shift in location from core to periphery for Fedecafé? Or did it reflect a larger structural transformation of the global coffee market as a whole?

Interestingly, sociologist John Talbot examines the "struggles over control of the coffee chain” in his book, Grounds for Agreement: (2004). He found that the leading coffee roaster and importer corporations in the United States were willing to cede to US governmental interests in signing onto the ICA agreement early on because they did not feel as if the quota and pricing system would fundamentally threaten their profitability. Yet, by the late 1960s and into the early 1970s, the "upgrading" aspirations of the central ICA producer countries began to seriously threaten the capital accumulation of roasting and importing companies located in consumer countries; and a series of conflicts emerged between exporter and importer countries over whether or not the ICA system should continue. The first conflict came at the time of the 1968 


\section{LESSONS FROM COLOMBIA 146}

ICA renegotiations. By then, Brazilian coffee capitalists had begun to roast their own instant coffee and sell them directly in the U.S. consumer market, effectively capturing $14 \%$ of the instant market by 1967. Perceiving this as a direct assault, U.S. roasters lobbied against the Brazilians, claiming that they were using "unfair trading practices." Though the U.S. pressure was effective in shutting the Brazilians out of the market, they were forced to accept the creation of a "diversification fund" collected by the ICA to finance the development of other agricultural export products and lesson producer-country reliance upon coffee as their primary source of income (Talbot 2004: 61-62).

The rescheduling of precise quotas and pricing was planned to occur in 1973 and then in 1976. Yet, due to the skyrocketing of coffee prices (following frosts that incapacitated the Brazilian sector, civil wars in Ethiopia and Angola, and political strife in Uganda that curtailed the volume of coffee entering the market), the ICA producer countries remained content to let the market rather than their own regulatory mechanisms guarantee high coffee prices. ${ }^{7}$ By the time of the next ICA meeting in 1979-80, U.S. delegates were pressured by the Carter Administration to accept the quota system due to a revival of political unrest in coffee producing countries, including the Sandanista Revolution in Nicaragua, the escalating civil wars in El Salvador, Guatemala and Angola, and the growth of guerrilla insurgency groups in Colombia. Yet, over the course of the 1980s the U.S. government's stance toward the ICA system became increasingly hostile, reflecting the interest of U.S. coffee corporations in eliminating the quotas and pricing arrangements and breaking the political alliances of the coffee exporting countries (Talbot 2004: 73).

The political alliances buttressing the ICA system was undermined by the closing years of the 1980s for at least three reasons. First, by the early 1980s many Third World countries had become highly dependent upon foreign loans to finance their national development policies and patronage systems. Thus, following the reversal of U.S. monetary policies and the drying up of loan money, many of these countries were faced with a pressing debt crisis that placed them at a structural disadvantage vis-à-vis the predominant international lending institutions. As a response, many turned to the World Bank and International Monetary Fund, the "lenders of last resort," who offered them "structural adjustment loans" only if they agreed to implement unpopular trade liberalization, export-promotion, and privatization measures (McMichael 2000). The largest ICA producer countries, including Colombia, were largely sheltered from such loans precisely because they maintained stable and relatively high revenues under the ICA system itself. Yet, those countries outside of the ICA altogether (including Thailand and the Philippines) and those countries with relatively minor quota niches within the ICA system (including the Dominican Republic, Honduras and Nicaragua) began to receive these loans, using them to finance the development or expansion of their own coffee export sectors. In other words, the U.S. (through the power it exercised through the World Bank and IMF) was able to utilize the financial vulnerability of those countries to finance the development of a whole new cluster of coffee exporting countries, many of whom were skeptical of the ICA system because their quota arrangements were fixed at low market share levels, because as new coffee producers they lacked the historical experience of effective collective action strategies, and/or because their domestic political situation lacked the types of class-based mobilizations that forced governments such as

\footnotetext{
${ }^{7}$ An "automatic quota” was established if the price were to fall below 78 cents/lb (Talbot 2004: 71-72)
} 
Colombia and Brazil to conceive of a coffee cartel as a means of ameliorating class conflicts (Stewart 1992: 240-241; Bates 1997: 138-139).

A number of authors also point to the growth of "tourist coffee" - coffee sold "illegally" outside of the ICA market - as another factor that undermined the ICA system. To be sure, under the ICA system the quotas were based upon periodic calculations of the productive capacity of each producer country. As a result, most countries produced above their quota limits and stockpiled this coffee as evidence of their productivity at the next round of ICA negotiations. Yet, by the 1980s, it became clear that many of the smaller and new producer countries were not only heavily stockpiling their excess coffee, but they were selling it below ICA prices in the tourist market. Unwilling to sit back and watch, eventually even the largest coffee producers such as Colombia and Brazil began selling there in order to take advantage of the profitability of this parallel market (Stewart 1992: 261-265; Akiyama 2001: 88; Talbot 2004: 78-79).

A final stake in the heart of the collective action efforts of the ICA producers came from the growing influence of finance capital in the global coffee market. On the one hand, coffee roasters and distributors became subject to the mergers and acquisitions typifying the rest of the U.S. economy. Not only did economic capital become concentrated into the hands of only a handful of coffee corporations (including Nestle, Philip Morris, Sara Lee and Proctor \& Gamble), but coffee itself came to reflect on a segment of the profit-making activities of these conglomerates. On the other hand, the 1980s witness an explosion of speculative trading on the coffee futures market, due to technical changes in the New York Coffee, Sugar and Cocoa Exchange that permitted the possibility of trading in options on futures contracts and stimulated the rise of commodity funds that introduced a whole new class of small-scale speculators into the market. Though full discussion of these financial activities is impossible in this paper, the impact of this increase in financial speculation was twofold. First, it loosened the connection between productive markets (related to the supply of coffee going into the market) and financial markets. This meant that producer countries began to lose their structural power to withhold coffee from the market in order to drive prices up. Second, it propelled an overall escalation in the volatility of coffee prices which meant that those coffee actors with the best knowledge over the instantaneous and detailed knowledge about shifts in coffee prices, supplies and markets - the U.S.-based conglomerates - were in the most favorable position to manipulate the market to their favor (Giovannucci et al. 2002: 16; Talbot 2004: 110-113).

John Talbot (2004: 89) points out that the fissures that emerged between clusters of countries at the time of the 1989 ICA accords was "simply a manifestation of the atomization of the Third World" at the time. Colombia, Brazil, Costa Rica and a number of Africa countries formed one bloc that was interested in prolonging the ICA quota system while the Central American countries allied with the U.S. formed another bloc interested in eliminating the system. In the end, the Central America-U.S. bloc succeeded in undermining the negotiation. And though the International Coffee Organization itself (the organizational body that instituted the ICA) was maintained, another round of the ICA quota system was attempted in 1993 and failed due to the persistent strength of the neoliberal-oriented coffee producers.

As we can see, these struggles along the global coffee commodity chain do indeed encapsulate the larger structural trends and dynamics of the global political economy at large. That is, the attempts and successes in "upgrading" by some coffee producer countries such as Colombia triggered responses by core-actors whose "core-like positions" were threatened. Rather than "downgrade", these actors used their control of the dominant political-economic institutions 


\section{LESSONS FROM COLOMBIA 148}

to restructure the global trade to their benefit, thereby forcing the competitive pressures back downwards along the chain. Moreover, as this "zero-sum game" highlights, the upgrading efforts by countries such as Colombia and Brazil was not only a threat to the core-like positions of U.S. importers, it also posed a threat to smaller producers and those countries excluded from the ICA system altogether. Thus, movement into and up the coffee commodity chain by these smaller countries was the mechanism that helped push the core-like position attained by Colombia and Brazil back downward. To summarize, we find evidence supporting the thesis that the hegemonic form of labor control established by Fedecafé was indeed premised upon their capacity to upgrade along the coffee chain. Once that core-like position was downgraded, the capacity for Fedecafé to maintain this consensual form of domination was undermined, and labor-capital relations at the local level spiraled out of control.

\section{From Despotism to a Crisis of Control (\& Back Again) in the Banana Region}

If the shift in nodal location along the commodity chain helps us explain the shift labor regime trajectory in Colombia's coffee region, can this same perspective assist us in an explanation of the shift from a despotic regime in the banana region to a crisis of control for local banana elites by the 1980s? And does it help explain the shift back to despotism by the mid-1990s? Of course, the crisis of control that emerged in Urabá in the 1980s cannot be explained by the "downgrading" of Colombian banana producers because, as we saw from the previous section, the node occupied by Urabá's banana capitalists was already "peripheral." So then how can we explain the shift in forms of labor control in Urabá?

The shift occurred as a direct response to the democratization process that began under the Betancur Administration (1982-1986), which opened up the space for banana workers to legitimately organize unions on the plantations and working-class political parties to run for local governmental positions without facing government-sanctioned military and police repression. The first step came in 1982, when Betancur granted official and unconditional amnesty for political prisoners and armed insurgents. Though such a move was a national level response, it was a symbolic step forward for Urabá's banana workers who understood it to mean that their organizational efforts on the plantations would be officially sanctioned (rather than repressed) by the central the state. A second step forward for the workers came when Betancur launched a series of peace negotiation strategies with the guerrillas themselves in 1984. Those each peace negotiation indeed eventually broke down (negotiations with the FARC lasted between 1984 and 1987 while the negotiations with the EPL lasted between 1984 and 1985), the political legitimacy granted to the guerrillas symbolized governmental recognition that their political demands for a further democratization of the regime were justifiable. By 1987-88, the Barco Administration continued the reforms by permitting the direct popular election of local gubernatorial and mayoral elections.

Such actions undertaken by the central state had a direct and immediate impact on capital-labor relations in Urabá. On the plantations, banana worker unions expanded dramatically. Sintagro membership jumped from 300 workers in 1984 to roughly 9000 workers by 1986 while Sintrabanano's membership jumped from 100 workers to roughly 4000 over the same period. By 1985, the percentage of plantations with organized unions rose to an estimated $60 \%$ (Carroll 2000: 177). As union density deepened, so came a growth in strike activity on the plantations, with the number of labor strikes jumping from virtually nothing in the mid-1970s to an average of 
12 by the closing years of the 1980s. Such labor militancy was effective in winning a number of key concessions, including an eight-hour workday, the establishment of two labor-courts in the region to oversee and mitigate violations in worker rights, an increase in real wages from an estimated average of $\$ 3,700-3,800$ Colombian pesos/month in 1978 to an average of $\$ 7,700$ per month by the middle of the decade (Hough 2007).

It was not only at the point of production that banana worker strength grew. In fact, over this period the FARC and EPL guerrilla groups established their own national political parties which gained important political positions in Urabá. By 1988, the FARC’s newly established Patriotic Union Party had organized a coalition with the EPL's Popular Front Party, winning the mayoral election of Urabá's largest municipality of Apartadó by 1988 as well as significant percentages of "county council" positions across the four municipalities comprising Urabá as a whole. And these electoral victories granted these worker-friendly parties with the authority to directly and favorably intervene in the labor-capital conflicts arising from the plantations, including the 1986 imposition of a tax on planters to finance greater worker concessions (Carroll 2000: 183, 204).

This political opening granted to Urabá's banana workers by the national executive provided them with the capacity to challenge the coercive form of domination imposed upon them by Augura and their allies in the Liberal Party who had formerly monopolized local political positions. Yet, Urabá's elites did not simply sit back and watch their political and economic power unravel. In fact, they correctly identified the fact that worker empowerment was a direct threat to their capacity to maintain their peripheral position with the global banana commodity chain. Jaime Henrique Gallo, the region's local Liberal Party leader expressed this frustration, stating that such workerist policies as the plantation tax was "a strategy against the economic system in which we live" and "a clear-cut class struggle... has been unleashed against us in the zone.” He responded by calling for a twofold strategy. First, knowing that the Colombian national military was openly opposed to the democratization and peace processes, he argued that local elites should use the political power that they still carried to lobby for the further militarization of the region. Second, he responded with a "thinly-veiled apology" for the establishment of paramilitary groups to be used against Urabá's working class if the military-proper was no longer willing to help them reassert their power. He wrote, "as long as (the president, the ministers, the governor, and the armed forces) give us slow, late solutions that make us despair, we must form our own strategies" (Carroll 2000: 183-185).

In terms of the former strategy, calls for a further militarization of the region did occur. This included the creation of a new battalion (Voltigeros) comprised of 800 soldiers in 1984, a new brigade (XI Brigada) in the neighboring department of Cordoba in 1987, a "Chief Military Headquarters" (Jefatura Militar) in Urabá proper in 1988, and another new brigade (X Brigada) and battalion (Francisco Paula de Velez) in 1989. By the end of the decade, the region became the most heavily militarized of the country in terms of troops per square kilometer (Carroll 2000: 213-214).

Though the region saw this impressive growth in its military presence, it was not the military proper that carried out the wave of elite violence in the region by the latter half of the 1980s. In fact, it was the creation of the a local paramilitary army, calling itself the Peasant SelfDefense Group of Cordoba and Urabá (ACCU), who took responsibility for these actions. In reality, the ACCU was simply the result of the implementation of Henrique Gallo's second strategy, and they were financed by a powerful coalition of local elites, including members of 


\section{LESSONS FROM COLOMBIA 150}

Augura (represented by banana planters and cattle ranchers), the Liberal Party, and an emergent class of narcotraffickers who began to purchase large tracts of land and establish cattle ranches in order to launder the excess liquidity the accumulated through the illegal narcotics trade. It is well noted that the ACCU had established paramilitary "bases" throughout the four banana-producing municipalities of Urabá, and that their repressive actions emerged due to direct military participation or because of the military's willful permission of such actions (Ramirez Tobón 1997: 127-134; Carroll 2000: 216; Dudley 2003). Nevertheless, the rise of the paramilitary presence in Urabá led to a number of repressive actions, including massacres on two banana plantation workers in 1988, the assassination of a number of Patriotic Union and Popular Front activists, as well as civilians in neighborhoods known to be their strongholds (Méndez 1990: 21). ${ }^{8}$ Though the number of incidents of military and paramilitary violence increased in Urabá throughout the 1980s, they were not effective in repressing the growing strength of banana unions whose strikes continued unabated and of workerist political parties who continued to gain ground in local elections (Carroll 2000; Hough 2007).

In 1990, the newly-elected President Gaviria (1990-1994) began a second round of peace negotiations with the EPL guerrillas, which led to their disarmament (except for a small radical fraction that remained armed) and participation in the Constitutional Assembly. As part of the demobilization package, Gaviria ordered the closing of the Jefatura Militar and promised to examine any linkages between military and paramilitary organizations, thereby making it clear to Urabá's elites that regional peace was a top national priority. As a result, a number of negotiations arose between Augura and Sintrainagro (a banana worker union formed through the fusion of Sintagro and Sintrabanano in 1989), which culminated in Sintrainagro agreement to halt its strike activity in order to promote Augura's demand of increased productivity on the plantations, the creation of "peace fund" (financed by Augura and the departmental government) to assist the reinsertion of demobilized EPL guerrillas, and the establishment of a "social pact" for the region that formally acknowledged Augura's responsibility in addressing the "basic needs" of the local population (Carroll 2000: 225; Rivera Zapata 2004). Interestingly, both the number of incidents of political violence committed by elites against the workers as well as the incidents of strike activity on the plantations dropped dramatically over the next two years (Hough 2007).

Yet, by 1992 the "social pact" proved to be an ineffective and temporary solution to the regions labor-capital problems. By then, Urabá's peace had for all intents and purposes ceased to be a "top national priority," and President Gaviria was actively advocating the passage of neoliberal legislation that would stimulate trade liberalization and agro-export promotion. In May, following the breakdown of peace negotiations with the FARC, the Gaviria Administration ordered a re-militarization of the region and instated a "decree of Internal Commotion" that granted the military greater freedom to carry out "counter-insurgency operations." The militaryparamilitary nexus were thus granted a "green light" to reinitiate an offensive against guerrillas,

\footnotetext{
${ }^{8}$ By the end of the 1980s, three presidential candidates had been assassinated, including the popular Liberal Luis Carlos Galán (August 1989), the Patriotic Union’s Bernardo Jaramillo (March 1990), and the M-19's Carlos Pizarro León-Gómez (April 1990). The Patriotic Union party of the FARC was particularly vulnerable to campaigns of terror and reactionary violence orchestrated by paramilitary groups affiliated with drug traffickers. By 1987, a little more than a year after their entrance onto the political stage, an estimated 111 Patriotic Union militants had been assassinated. In 1988, another 276 were killed, and by 1989138 were added to the death march (Dudley 2004: 130). Gonzalo Sánchez notes that "their entire party ...was decimated between 1989 and 1992” (Sánchez 2001: 6).
} 
which they interpreted as consisting of not only insurgents themselves, but also political and community activists, human rights workers, and other individuals who threatened the interests of Urabá’s elites.

Whereas the earlier wave of paramilitary violence by the ACCU was ineffective in repressing worker militancy, consisting of roughly a few hundred armed combatants,

by the middle of the 1990s the paramilitaries throughout the country had grown in strength and manpower, leading to a paramilitary alliance known as the United Self-Defense Forces of Colombia (AUC), consisting of roughly 8000 regular fighters by the middle of the decade (Richani 2002: 123). The power of the AUC was soon felt throughout the region, leading to the complete elimination of the EPL dissident faction as well as the expulsion of the $5^{\text {th }}$ Front of the FARC from the region. And without the protection of the guerrilla organizations, Urabá's political and union activists soon fell prey. An estimated 1554 UP-affiliated individuals were assassinated, what some consider to be the "total annihilation" of the UP party (Sánchez 2001: 6; Livingstone 2004: 222).

The rise of paramilitarism was effective in repressing the wave of worker militancy that arisen since the 1980s (as seen from Figure 6 below); and with this the region reverted back to the despotism characterizing its labor regime before the democratization period. In 2004, the Commander of the AUC operating in Urabá stated, "I was appointed by the Estado Mayor (AUC Central Command) to retake 'el Calima' five years ago. But the Banana Bloc was initiated by me as a measure of self-defense. I started here and will have finished my task when I turn my arms in” (El Tiempo 2004).

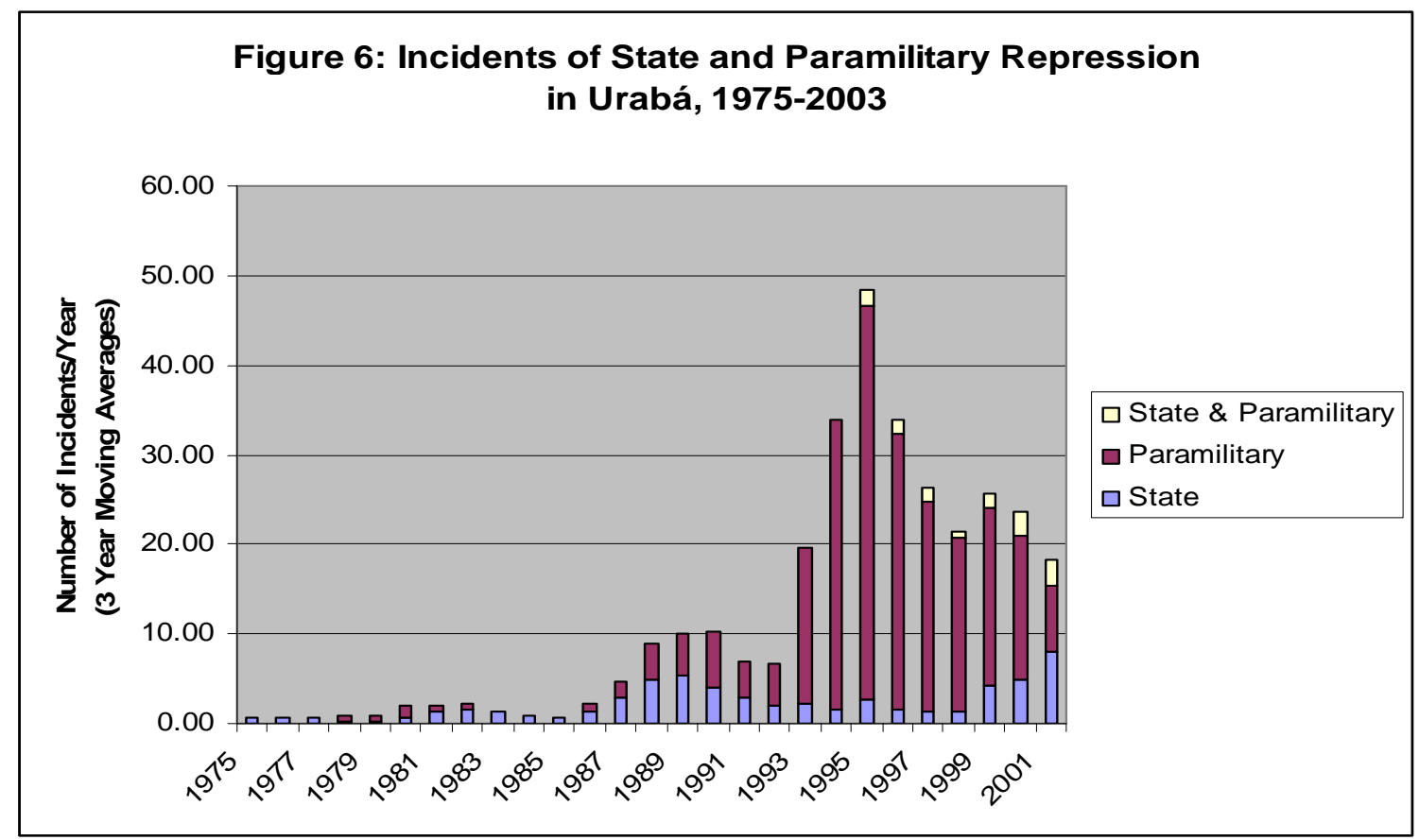

Sources: CINEP (Banco de Datos); El Tiempo. ${ }^{9}$

${ }^{9}$ For an explanation of the data sources see footnote 6. 


\section{LESSONS FROM COLOMBIA 152}

In short, we see that the democratization of the Colombia regime, rather than a structural transformation of the global banana trade itself, was responsible for the shift in forms of labor control in the banana region of Urabá. Not only were Colombia's banana exporters already positioned in a crowded peripheral along the banana chain, but the structure of the "dollar market" in which they were embedded was itself governed by neoliberal, "free market" mechanisms that only intensified the competition between exporters and limited their capacity to organize collective action efforts in a similar way to that achieved by coffee producers under the International Coffee Agreement. The emergence of "global banana wars" in the mid-1990s is the exception that proves the rule. By then, a number of Latin American producers including Colombia, Ecuador and the Central American countries joined the United States in its efforts to use international trade stipulations to force the European Union to liberalize its "APC market" and accept the importation of bananas from the "dollar market". In this sense, we see that the actions of Colombia were similar to those of the newly-emergent coffee exporting countries who felt that the International Coffee Agreement quota system excluded them from access to larger market shares and forced them into a competitive position along the coffee chain. Meanwhile, the axis of conflict positions APC banana exporters against "dollar" banana exporters, to the ultimate advantage of the banana importing countries themselves, who can use this intensification of market competition occurring within the lowest nodes of the banana chain to maintain their core-like profitability.

\section{CONCLUSION}

As we saw from the case studies of forms of labor control in Colombia's coffee and banana sectors, their distinct forms (puzzle \#1) as well as the transformation in these forms (puzzle \#2) cannot be understood without locating them within their larger structural and institutional contexts. In terms of the first puzzle, the formation and perpetuation of hegemonic relations linking the activities of Colombia's smallholding coffee producers to the capital accumulation interests of the nation's exporting elites was the result of Fedecafé's interventions in the local coffee market, which itself was premised upon their effectiveness in not only upgrading up from a peripheral to a core-like node along the global coffee commodity chain, but also by fundamentally restructuring that chain in order to institutionalize that shift. In contrast, efforts by Colombia's banana exporters to upgrade and/or fundamentally alter the structure of the banana commodity chain were unsuccessful. Stuck in a peripheral node and faced with intense market competition from other banana exporters, Urabá's elites came to rely upon the coercive force of the Colombian state (and later upon the paramilitaries) to effectively repressive worker attempts at demanding concessions, concessions that would have cut into the capital accumulated of banana plantation owners and threatened their competitive position within the world banana market.

In terms of the second puzzle, we also find evidence supporting the centrality of the macro-structural and systemic relations between core and periphery, and the core-like and periphery-like locations along each respective commodity chain in explaining the form of laborcapital relations. Yet, the shift in the types of labor control in each (from consensual domination to a crisis of control in the coffee region and from coercive domination to a crisis and back in the 
banana region) stemmed from different causes. The shift in the coffee region's labor-capital relations reflects the "zero-sum game" outlined by Arrighi and his collaborators. That is, the successful upgrading of the leading coffee exporting countries (Colombia included) eventually came to threaten the core-like position of roaster and distributor corporations operating in the core countries themselves (upgrading entails downgrading by definition). The restructuring the coffee chain along neoliberal lines reflected the larger historical-structural trend by which core countries such as the United States reasserted their power over the commodity chain and re-peripheralized former upgraders to downgraded positions. At the world-systemic level, we see that this effort to reassert their power by rescinding on the International Coffee Agreement that buttressed the upgrading of Colombian producers reflected a decision by the U.S. global hegemonic power to sacrifice its own efforts at global legitimacy in order to safeguard its own attempts to reel in the profits accruing to the country's coffee capitalists.

In terms of Colombia's banana sector, the shift in labor-capital relations did not come as the result of such efforts to re-peripheralize actors through neoliberal initiatives precisely because Urabá's plantations were already located within a peripheral node along the banana chain. Instead, the shift came as the result of the democratization of the political regime, which opened up official state-sanctioned support for the formation of banana unions and workerist political parties. It was the success of these worker efforts to organize on the plantations and in the political sphere that came to fundamentally threaten the peripheral position, and therefore capital accumulation, of Urabá's banana capitalists. It was only through the formation of paramilitary groups that Urabá's workers came back under the control of capital, though this entailed the total annihilation of any form of worker collective action.

The case of Urabá highlights a structural contradiction associated with peripheral producers. Unable to accumulate enough capital to both invest the establishment of a hegemonic pact at the local level as well as reinvest in capital accumulation processes (as their core counterparts can), peripheral capitalists must shift between what Beverly Silver (2003) aptly calls, "crises of legitimacy" and "crises of profitability." To invest too far in one direction will lead to a powerful reaction from the opposite direction. In Urabá, the democratization of the regime pushed in the direction of legitimacy, while the formation of the politically-exclusive National Front (in 1957) as well as the rise and consolidation of the paramilitaries (in the 1990s) pushed in the other direction. This example, I believe, is illustrative of Arrighi's point that capitalist accumulation along any given chain continues through the exclusion of most chain actors from access to that wealth generated. This capacity exclude peripheral actors from access to the greatest profits along a chain is what makes the market for that commodity capitalist. Moreover, we see that the perpetual struggle to peripheralize and re-peripheralize chain actors by externalizing competitive market pressures downwards has direct bearing on labor-capital struggles. While capitalists in core locations can shift market competition downwards along the chain, thereby assuring enough wealth to redistribute to their own workforces, the capitalists of the periphery internalize their market competition pressures by forcing these pressures onto the backs of their workers. The legitimacy of local labor regimes in the periphery is therefore much more tenuous than that of the core.

This brings me to two final points. First, the use of commodity chain locations to explain labor regime dynamics is unconventional. In fact, Jennifer Bair (2005: 154) has pointed out that the literature on global commodity chains (and its variants, including global production networks and global value chains) has become increasingly oriented analytically towards the meso-level of 


\section{LESSONS FROM COLOMBIA 154}

sectoral dynamics and/or the micro-level of firm upgrading rather than maintaining the macrostructural and world-systemic orientation of its founders. And in doing so, she argues that the recent generation tends to overlook "the broader political-economic environment in which chains operate, including the institutional and systemic factors that shape commodity chains and condition the outcomes associated with them.” By focusing on the interrelationship between class struggles, labor regimes, and commodity chain dynamics, I hope to contribute to a small but growing literature that examines the politics of chains and the agency of workers in constituting those chains (Raikes et al. 2000; Gellert, 2003; Talbot 2004; Levy 2008; Cumbers et al. 2008; Bair 2009).

Finally, the current debate in Colombia over the protracted nature of the country's political conflict appears to have indeed entailed its own historical memory loss. Whereas the older body of literature sought causal explanations precisely in such variables as the nature of the political regime and economic development models, the recent tendency in the literature is to cast blame for its protracted nature on the motivations of the paramilitaries as well guerrillas. This frustration with the guerrillas as well as paramilitaries is reflected most deeply by the continuing and wide support for the nation's hard-line right-wing President Álvaro Uribe Velez, who initiated peace negotiations with the paramilitaries and refuses to do the same with the guerrillas. Yet, as we see from the case study of Urabá, the paramilitaries were not a region-specific response to the rise of guerrilla groups, as some have argued (Sánchez 2001). Rather, they were a response to the threats posed by empowered workers to region specific modes of capital accumulation. Thus, the struggle between guerrillas and paramilitaries is simply a reflection of the larger structural conflict between capital and labor in specific sectors of the country. In the case of Urabá, we see the victory of capital. In the case of Viejo Caldas, we continue to see a "crisis of control" characterized by pockets of guerrilla groups adjacent to pockets of paramilitarism, pockets of collective mobilization adjacent to pockets of conservative reactionaries. One quickly loses sight of the larger significance of these struggles by failing to adequately locate them within their proper world historical context. 


\section{APPENDIX}

Map 1: The Banana Axis and Coffee Axis Regions of Colombia

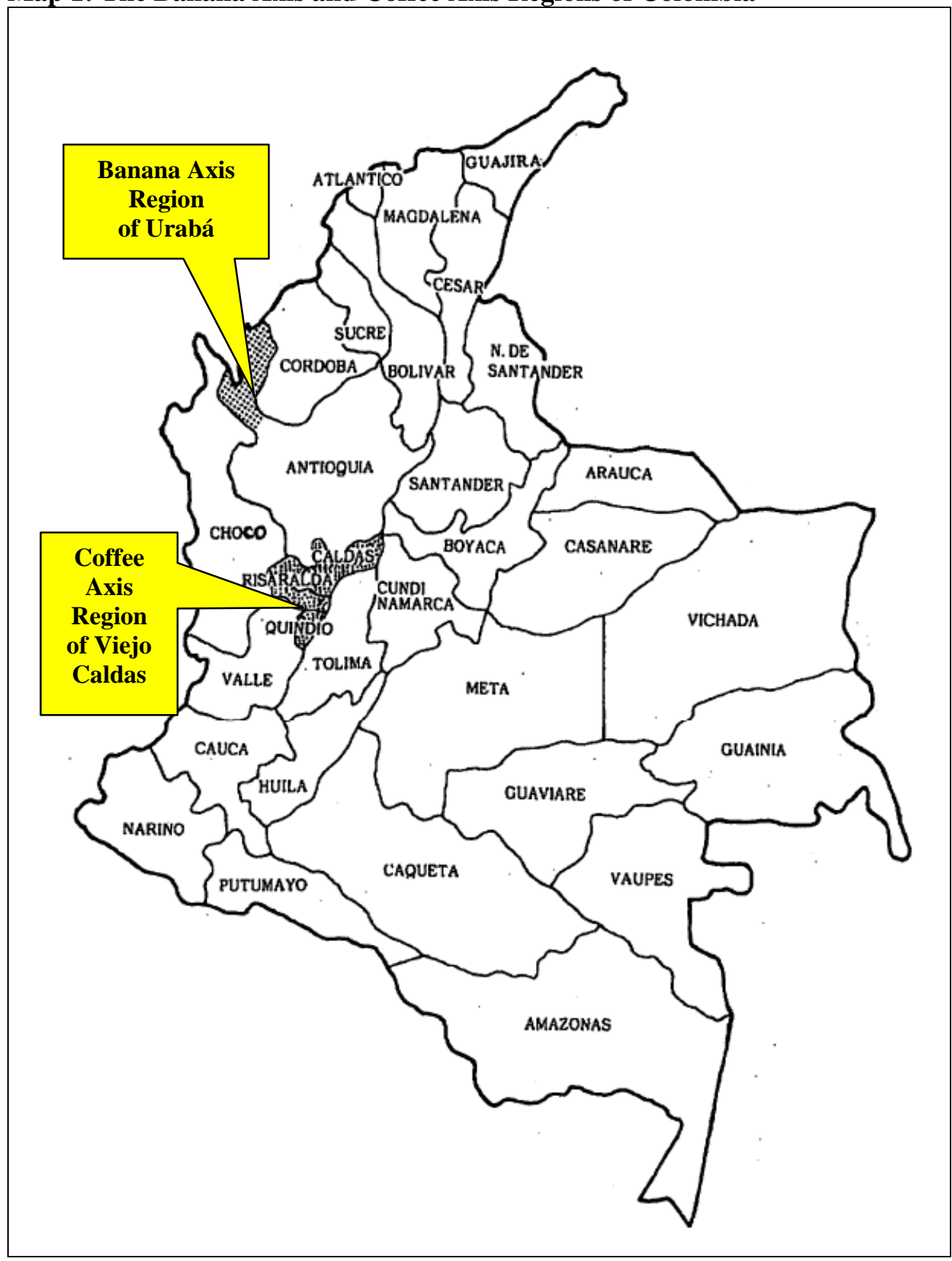


Figure 7: International Coffee Price, US $\$$ /pound in Constant Terms (2001)

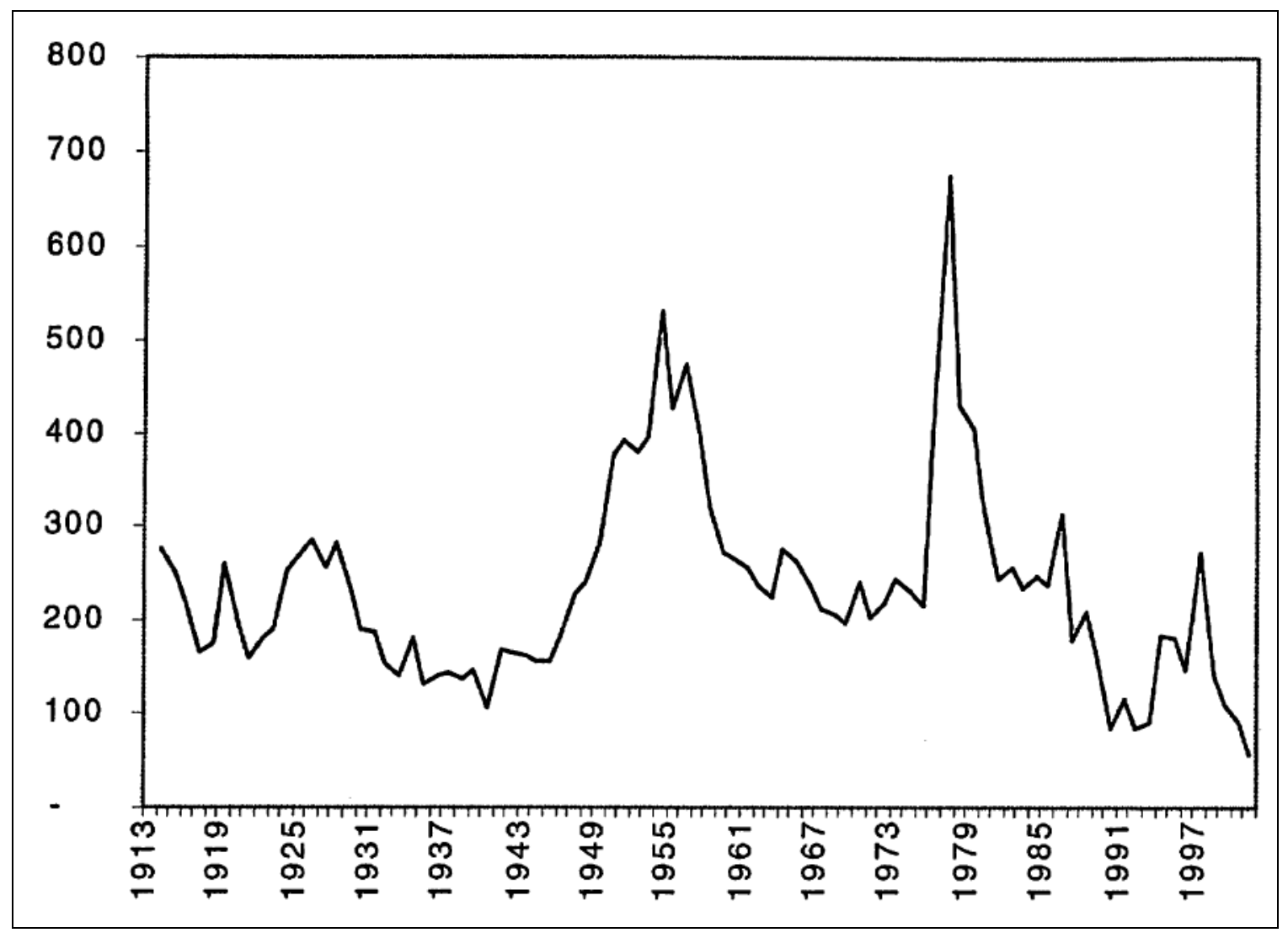

Source: International Coffee Organization, printed in Giovannucci et al. (2002)

\section{ACKNOWLEDGEMENTS}

The author would like to thank Farshad Araghi, Mark Harvey, Kevan Harris, Mehmet Gurses, and Renat Shaykhudinov as well as the three anonymous reviewers from JWSR for their constructive comments and critiques on earlier drafts.

\section{REFERENCES}

Akiyama, Takamasa, John Baffes, Donald Larsen, and Panos Varangis. 2001. Commodity Market Reforms: Lessons of Two Decades. World Bank, Washington, D.C.

Archila, Mauricio, Avaro Delgado, Martha Cecilia Garcia, Esmeralda Prada. 2002. 25 Anos de Luchas Sociales en Colombia, 1975-2000. Bogota: CINEP.

Arrighi, Giovanni. 1990. "The Developmentalist Illusion: A Reconceptualization of the Semi- 
Periphery,” in W. Martin ed., Semi-Peripheral States in the World-Economy. Westport, CT: Greenwood Press.

Arrighi, Giovanni. 2001. The Long Twentieth Century: Money, Power, and the Origins of Our Times. London-New York: Verso.

Arrighi, Giovanni. 2007. Adam Smith in Beijing: Lineages of the Twentieth Century. London and New York: Verso Press.

Arrighi, Giovanni and Jessica Drangel. 1986. "The Stratification of the World Economy: An Exploration of the Semiperipheral Zone." Review 10:9-74.

Arrighi, Giovanni and Fortunata Piselli. 1987. "Capitalist Development in Hostile Environments: Feuds, Class Struggles, and Migrations in a Peripheral Region of Southern Italy." Review $\mathrm{X}$ : 649-751.

Arrighi, Giovanni and Beverly J. Silver eds.. 1999. Chaos and Governance in the Modern WorldSystem. Minneapolis and London: University of Minnesota Press.

Bair, Jennifer. 2005. "Global Capitalism and Commodity Chains: Looking Back, Going Forward." Competition and Change 9:153-180.

Bair, Jennifer. 2009. ed., Frontiers of Commodity Chain Research. Stanford, CA: Stanford University Press.

Bates, Robert. 1997. Open-Economy Politics: The Political Economy of the World Coffee Trade. Princeton, NJ: Princeton University Press.

Bergquist, Charles. 1986. Labor in Latin America: Comparative Essays on Chile, Argentina, Venezuela and Colombia. Stanford, California: Stanford University Press.

Bergquist, Charles. 2001. "Waging War and Negotiating Peace: The Contemporary Crisis in Historical Perspective,” in Bergquist et al., Violence in Colombia, 1990-2000: Waging War and Negotiating Peace. Wilmington, DE: Scholarly Resources Inc.

Botero Herrera, Fernando. 1990. Urabá: Colonización, Violencia y Crisis del Estado. Medellín: Editorial Universidad de Antioquia.

Braverman, Harry. 1974. Labor and Monopoly Capital: The Degradation of Work in the Twentieth Century. New York: Monthly Review Press.

Bronfrenbrenner, Kate, et al. 1998. Organizing to Win: New Research on Union Strategies. Ithica and London: Cornell University Press.

Bucheli, Marcelo. 2003. "United Fruit Company in Latin America." Pp. 80-100 in Banana Wars: Power, Production, and History in the Americas, edited by Striffler and S. a. M. Moberg. Durham, NC: Duke University Press.

Bucheli, Marcelo. 2005. Bananas and Business: The United Fruit Company in Colombia, 18992000. New York, NY: New York University Press.

Burawoy, Michael. 1983. "Between the Labor Process and the State: The Changing Face of Factory Regimes Under Advanced Capitalism,” American Sociological Review: Vol. 48, No. 5, (Oct: 587-605)

Burawoy, Michael. 1985. The Politics of Production: Factory Regimes under Capitalism and Socialism. London: Verso Books.

Cardoso, Fernando Henrique and Enzo Faletto. 1979. Dependency and development in Latin America Berkeley, CA: University of California Press.

Carroll, Leah. 2000. "Violent Democratization: The Effect of Political Reform on Rural Social Conflict in Colombia." Sociology, University of California at Berkeley, Berkeley, CA.

Castillo, Jorge Enrique Robledo. 1998. El Café en Colombia: Un Análisis Independiente. Bogota: 


\section{LESSONS FROM COLOMBIA 158}

El Ancora Editores.

Centro de Investigación y Educación Popular. Banco de Datos. http://www.cinep.org.co/

Chernick, Marc. 1991. "Insurgency and Negotiations: Defining the Boundaries of the Political Regime in Colombia." Doctoral Dissertation Thesis, Department of Political Science, Columbia University, New York.

Chomsky, Aviva. 2008. Linked Labor Histories: New England, Colombia, and the Making of a Global Working Class. Durham and London: Duke University Press.

Consejo Nacional de Política Económica y Social (CONPES). 2004. "Seguimiento y Directrices para el Nuevo Enfoque de la Política Cafetera." Departamento Nacional de Planeación,, Bogota.

Cubides, Fernando, Jaime Arocha, and Myriam Jimeno. 1998. Las Violencias: Inclusión Creciente. Bogotá: Utopica Ediciones.

Cumbers, Andy, Corinne Natival and Paul Routledge. 2008. "Labour Agency and Union Positionalities in Global Production Networks,” Journal of Economic Geography, Vol. 8, pp. 369-387.

Diamond, Larry, Jonathan Hartlyn, Juan J. Linz, and Seymour Martin Lipset, and editors. 1999. "Democracy in developing countries: Latin America." Boulder, CO: Lynne Rienner Publishers.

Dudley, Steven. 2004. Walking Ghosts: Murder and Guerrilla Politics in Colombia. New York \& London: Routledge.

Edwards, Richard. 1979. Contested Terrain. New York: Basic Books.

Ehrenreich, Barbara and Arlie Hochschild. 2002. Global Woman: Nannies, Maids, and Sex Workers in the New Economy. New York: Henry Holt and Company.

El Tiempo, 2004. http://www.eltiempo.com/archivo/documento/MAM-1549306

Food and Agriculture Organization (FAO). 1986. "The world banana economy 1970-1984: structure, performance and prospects." FAO Economic and Social Development Paper, edited by C. a. T. Division. Rome, Italy: Food and Agriculture Organization.

Foran, John, ed. 2003. The Future of Revolutions: Rethinking Radical Change in the Age of Globalizations. New York: Zed Books.

Gallego, Carlos Medina. 1990. Autodefensas, paramilitares y narcotráfico en Colombia: Orígen, desarrollo y consolidación (el caso Puerto Boyacá). Bogotá: Editorial Documentos Periodísticos.

Gellert, Paul. 2003. "Renegotiating a Timber Commodity Chain: Lessons from Indonesia on the Political Construction of Commodity Chains, Sociological Forum, Vol. 18: 1, pp. 53-84.

Gilhodes, Pierre. 1972. Las Luchas Agrarias en Colombia. Bogotá: Editorial Tigre de Papel.

Giovannucci, Daniele, Jose Leibovich, Diego Pizano, Gonzalo Paredes, Santiago Montenegro, Hector Arevalo, and Panos Varangis. 2002. "Colombia: Coffee Sector Study." CEDE Centro de Estudios sobre Desarrollo Económico, Facultad de Economía, Universidad de los Andes, Bogota.

Gramsci, Antonio. 1971 [1926]. Selections from the Prison Notebooks. New York, NY: International Publishers.

Guha, Ranajit. 1992. "Dominance without Hegemony and Its Historiography.” R. Gupta, ed. Subaltern Studies 4, 210-305. New York: Oxford University Press.

Harvey, David. 2003. The New Imperialism. New York: Oxford University Press.

Herrera, Fernando Botero. 1990. Urabá : Colonización, violencia y crisis del Estado. Medellín: 
Universidad de Antioquia.

Hopkins, Terence and Immanuel Wallerstein. 1986. "Commodity Chains in the World-Economy Prior to 1800." Review X:157-170.

Hough, Phillip Andrew. 2007. "Trajectories of Hegemony and Domination in Colombia: A Comparative-Historical Analysis of Class Relations in the Coffee, Banana and FrontierCoca Regions from the Rise of Developmentalism to the Era of Neoliberal Globalization." Doctoral Dissertation Thesis, Sociology, The Johns Hopkins University, Baltimore, MD.

International Confederation of Free Trade Unions (ICFTU). 2002. " Annual Survey of Violations of Trade Union Rights: 2002." International Confederation of Free Trade Unions.

Jenkins, J. Craig and Kevin Leicht. 1997. "Class Analysis and Social Movement Theory: A Critique and Reformulation.” In John R. Hall et al., Reworking Class: Cultures and Institutions of Economic Stratification and Agency. Ithica, NY: Cornell University Press.

Jonas, Andrew E. G. 1996. "Local Labour Control Regimes: Uneven Development and the Social Regulation of Production,” Regional Studies, Vol. 30: 4, pp. 323-338.

Joseph, Gilbert and Daniel Nugent. 1994. "Everyday Forms of State Formation: Revolution and the Negotiation of Rule in Modern Mexico." Durham, NC: Duke University Press.

Klein, Naomi. 2007. The Shock Doctrine: The Rise of Disaster Capitalism. New York: Holt and Company, Ltd.

Krasner, Stephen D. 1973. "Business Government Relations: The Case of the International Coffee Agreement." International Organization 27:495-516.

Kuhn, Thomas. 1962. The Structure of Scientific Revolutions. Chicago: University of Chicago Press.

Kutschbach, Mario Samper. 1995. "In Difficult Times: Colombian and Costa Rican Coffee Growers from Prosperity to Crisis, 1920-1936." in Coffee, Society, and Power in Latin America, edited by L. Gudmundson, W. Roseberry, and M. S. Kutschbach. Baltimore and London: Johns Hopkins University Press.

Lee, Ching Kwan. 2007. Against the Law: Labor Protests in China's Rustbelt and Sunbelt. Berkeley and Los Angeles: University of California Press.

LeGrand, Catherine. 2003. "Colombian Bananas, Peasants, and Wage Workers." in Work, Protest, and Identity in Twentieth-Century Latin America, edited by V. C. Peloso. Wilmington, DE: Scholarly Resources Inc.

Levy, David. 2008. "Political Contestation in Global Production Networks," Academy of Management Review, Vol. 33, No. 4, 943-963.

Livingstone, Grace. 2004. Inside Colombia: drugs, democracy and war New Brunswick, N.J.: Rutgers University Press.

London, Christopher. 1995. "From Coffee Consciousness to the Coffee Family: Reformation and Hegemony in Colombia's Coffee Fields." in 1995 Annual Meeting of the Latin American Studies Association. Washington, D.C.: Unpublished.

London, Christopher. 1997. "Class Relations and Capitalist Development: Subsumption in the Colombian Coffee Industry, 1928-1992." The Journal of Peasant Studies 24:269-295.

London, Christopher. 1999. "Desarollismo, Democracia y la Crisis Cafetera: Una Interpretación Cultural." Pp. 95-149 in Conflictos Regionales: La Crisis del Eje Cafetero, edited by Gonzalo Sánchez et al. Bogota: IEPRI \& FESCOL.

Martz, John D. 1997. The Politics of Clientelism: Democracy and State in Colombia. New 


\section{LESSONS FROM COLOMBIA 160}

Brunswick, NJ: Transaction Publishers.

Marx, Karl. 1976 [1867]. Capital: A Critique of Political Economy, Volume One. New York: Vintage Books.

Mazur, Jay. 2000. "Labor's New Internationalism," Foreign Affairs: Vol. 79, No. 1, January/February.

McMichael, Philip. 2000. Development and Social Change: A Global Perspective. Thousand Oaks, CA: Pine Forge Press.

Méndez, Juan E. 1990. "The "Drug war" in Colombia: the neglected tragedy of political violence." Human Rights Watch, New York, NY

Neira, Mauricio Archila, Álvaro Delgado, Martha Cecilia Garcia, and Esmeralda Prada. 2002. "25 años de luchas sociales en Colombia, 1975-2000." Bogotá: CINEP.

Ocquist, Paul. 1978. Violencia, conflicto y política en Colombia. Bogotá: Banco Popular.

O'Donnell, Guillermo, Philippe C. Schmitter, and Laurence Whitehead. 1993. "Transitions from Authoritarian Rule: Latin America." Baltimore and London: The Johns Hopkins University Press.

Oquendo, Catalina. 2004. "Le llego la hora al 'bloque Bananero'." in El Tiempo. Bogota.

Ortiz, Sutti. 1999. Harvesting Coffee, Bargaining Wages: Rural Labor Markets in Colombia, 1975-1990. Ann Arbor, MI: University of Michigan Press.

Ortiz Sarmiento, Carlos Miguel. 1992. "The 'Business of the Violence': The Quindío in the 1950s and 1960s," in Bergquist et al., Violence in Colombia: The Contemporary Crisis in Historical Perspective. Wilmington, DE: Scholarly Resources Inc.

Oxfam. 2002. Mugged: Poverty in your Coffee Cup. Oxfam, Washington D.C.

Oxfam. 2003. Walk the Talk: A Call to Action to Restore Coffee Farmers Livelihoods. Oxfam, Washington D.C.

Palacios, Marco. 1980. Coffee in Colombia, 1850-1970: An Economic, Social and Political History. Cambridge, UK: Cambridge University Press.

Ponte, Stefano. 2001. "The 'Latte Revolution'? Winners and Losers in the Restructuring of the Global Marketing Chain." Centre for Development Research Working Paper 01.3.

Raikes, Philip, Michael Friis Jensen, and Stefano Ponte. 2000. "Global commodity chain analysis and the French filière approach: comparison and critique." Economy and Society 29:390 417.

Ramírez Tobón, William. 1997. Urabá: los inciertos confines de una crisis. Santa Fe de Bogotá: Planeta.

Ramírez, Luis Fernando, Gabriel Silva, Luis Carlos Valenzuela, Álvaro Villegas, and Luis Carlos Villegas. 2002. "El Café, Capital Social Estratégico: Informe Final, Comisión de Ajuste de la Institucionalidad Cafetera." Bogota: Ministerio de Hacienda y Crédito Publico, Gobernación de Colombia.

Raynolds, Laura. 2003. "The Global Banana Trade." Pp. 23-47 in Banana Wars: Power, Production, and History in the Americas, edited by Striffler and Moberg. Durham, NC: Duke University Press.

Richani, Nazih. 2002. Systems of Violence: The Political Economy of War and Peace in Colombia, Edited by J. N. Rosenau. Albany, NY: SUNY Press.

Robledo Castillo, Jorge Enrique. 1998. El Café en Colombia: Un Análisis Independiente. Bogota: El Áncora Editores.

Rojas, Cristina and Judy Meltzer. 2005. Elusive Peace: International, National, and Local 
Dimensions of Conflict in Columbia. New York: Palgrave Macmillan.

Roldán, Mary. 2002. Blood and Fire: La Violencia in Antioquia, Colombia, 1946-1953 Durham, NC: Duke University Press.

Sánchez, Gonzalo. 2001. "Introduction: Problems of Violence, Prospects for Peace." In Bergquist et al., Violence in Colombia, 1990-2000: Waging War and Negotiating Peace. Wilmington, DE: Scholarly Resources Inc.

Sarmiento, Carlos Miguel Ortiz. 1992. "The "Business of the Violence": The Quindío in the 1950s and 1960s." in Violence in Colombia: Contemporary Crisis in Historical Perspective, edited by C. B. e. al. Wilmington, DE: Scholarly Resources, Inc.

Sassen, Saskia. 1998. Globalization and Its Discontents: Essays on the New Mobility of People and Money. New York: The New Press.

Scott, James C. 1985. Weapons of the Weak: Everyday Forms of Peasant Resistance. New Haven, CT: Yale University Press.

Seidman, Gay. 1994. Manufacturing Militance: Workers' Movements in Brazil and South Africa, 1970-1985. Berkeley and Los Angeles: University of California Press.

Silver, Beverly. 2003. Forces of Labor: Workers' Movements and Globalization since 1870. Cambridge, UK, New York, NY, USA: Cambridge University Press.

Silver, Beverly and Eric Slater, 1999. "The Social Origins of World Hegemonies,” in Arrighi and Silver, Chaos and Governance in the Modern World System. Minneapolis and London: University of Minnesota Press.

Stewart, Randal G. 1992. Coffee: The Political Economy of an Export Industry in Papua New Guinea. Boulder, Colorado: Westview Press.

Striffler, Steve and Mark Moberg, eds. Banana Wars: Power, Production, and History in the Americas. Durham and London: Duke University Press.

Talbot, John M. 2004. Grounds for Agreement: The Political Economy of the Coffee Commodity Chain. New York: Rowman \& Littlefield Publishers, Inc.

Tilly, Charles. 1995, “Globalization Threatens Labor's Rights," International Labor and Working-Class History, Number 47, Spring, pp. 1-23.

United States Labor in the Americas Project (USLEAP). http://www.usleap.org/usleapcampaigns.

Wallerstein, Immanuel. 1974. The Modern World System I: Capitalist Agriculture and the Origins of the European World-Economy in the Sixteenth Century. New York: Academic Press.

Zamosc, Leon. 1986. The Agrarian Question and the Peasant Movement in Colombia: Struggles of the National Peasant Association (1967-1981). Cambridge \& New York: Cambridge University Press.

Zapata, Guillermo Rivera. 2004. "El Modelo de Concertación en Urabá visto por SINTRAINAGRO." Revista Augura 1:27-30.

Zolberg, Aristide. 1999. "Matters of State: Theorizing Immigration Policy,” in Charles Hirshman et al., The Handbook of International Migration: The American Experience. New York: Russell Sage Foundation. 